\title{
Distribution and Biology of Blue Hake (Antimora rostrata Günther 1878) in the Northwest Atlantic with Comparison to Adjacent Areas
}

\author{
D. W. Kulka, M. R. Simpson and T. D. Inkpen \\ Department of Fisheries and Oceans \\ P. O. Box 5667, St. John's, Newfoundland, Canada A1C 5X1
}

\begin{abstract}
Blue hake (Antimora rostrata) are continuously distributed in slope waters off North America and into the Northeast Atlantic. This study focuses on their distribution from the Scotian Shelf in the south to the continental slope just south of Davis Strait. Although most survey effort took place at less than $500 \mathrm{~m} 91 \%$ of survey sets containing blue hake occurred at greater than $500 \mathrm{~m}$. They were found as shallow as $200 \mathrm{~m}$, but percent occurrence at less than $500 \mathrm{~m}(0.25 \%)$ was much lower than at depths exceeding $500 \mathrm{~m}$ (reaching $70 \%$ at $>1400 \mathrm{~m}$ ). Catch rate increased steadily to the maximum depths fished with commercial gear and peaked at about $1400 \mathrm{~m}$ in survey trawls, although depths greater than $1200 \mathrm{~m}$ were poorly sampled. Deep (1 371-2 286 m) longline sets from the 1960s indicated that blue hake were relatively common beyond the standard depths of either scientific surveys or commercial fishing. The deepest capture was from the deepest set fished at $2286 \mathrm{~m}$. Catch rate increased faster with depth in the southern part of our study area. Sets with blue hake spanned a range of bottom temperatures between 0.9 and $8.7^{\circ} \mathrm{C}$, but $97 \%$ of the survey sets with blue hake were associated with bottom temperatures greater than $3^{\circ} \mathrm{C}$ and less than $4.5^{\circ} \mathrm{C}$. Fish size (total length or TL) ranged between 5 and $65 \mathrm{~cm}$. Only 29 of 74569 fish measured from otter trawls were less than $15 \mathrm{~cm}$, but in longline catches, 37 of 867 fish averaging $10 \mathrm{~cm} \mathrm{TL}$ were taken, amongst the smallest recorded worldwide. Previous studies in US waters found no evidence of spawning and scant evidence of mature individuals and it was thought that spawning might take place to the north in Canadian waters; however, no mature fish, eggs or larvae have been found. The key meristic character used to distinguish North Pacific blue hake from those in other parts of the world was the count of gill filaments. We found considerable overlap in the range of number of gill filaments from our study area compared with those in the North Pacific.
\end{abstract}

Keywords: Antimora rostrata, biology, blue hake, depth, distribution, Davis Strait, Labrador Shelf, length/sex, Scotian Shelf

\section{Introduction}

Blue hake (Antimora rostrata Günther, 1878), sometimes referred to as the flatnose codling in reference to its flattened rostrum, is a member of the family Moridae. The genus, originally described by A. Günther (British Museum) in 1878 from specimens taken during Challenger voyages in the Indian and South Atlantic oceans was subsequently found to be a common inhabitant of slope waters in all oceans. The genus Antimora, formerly divided into five species, was amalgamated to a single species retaining the original name, A. rostrata by Schroeder (1940). Small (1981) then proposed dividing the genus into two species, A. microlepis inhabiting the North Pacific Ocean and $A$. rostrata in all other areas including the Atlantic, primarily based on differences in one morphometric relationship and one meristic count.
Blue hake is one of the most abundant fish species inhabiting bathyal depths. Grey (1956) provided the earliest summary of its global distribution and Small (1981) updated the records. Based on these and numerous other published records, it has been reported in varying concentrations in the Atlantic and Pacific distributed mainly on the continental slopes between 400 and $3000 \mathrm{~m}$ (Wenner and Musick, 1977).

In the Northeast Atlantic, blue hake is widely distributed from waters northwest of Norway (as a minor by-catch in commercial catches, P. I. Savvatimsky, Polar Institute of Marine Fisheries and Oceanography, Murmansk, Russia, pers. comm.) to the slope waters of the Hebrides, west of Britain (Gordon and Duncan, 1985; Gordon et al. 1996), south to Portugal (Sanches, 1989) and Africa (Barnard, 1925; Merritt and Marshall, 1980). In the 
mid-Atlantic, it is common on the northern part of the mid-Atlantic Ridge and south of Iceland (Magnusson, 2001).

In the Northwest Atlantic, blue hake has been reported as far south as the Bahamas (Sulak, 1984), off the Carolinas and Cape Hatteras (Bigelow and Schroeder, 1953; Goode and Bean, 1895, Wenner and Musick, 1977), on the southern slope of Georges Bank and from the Scotian Shelf north to the Labrador Shelf (Cross et al., 1973; Goode and Bean, 1879, 1895; Haedrich and Polloni, 1974; Haedrich et al., 1975; Markle and Musick, 1974; Musick et al., MS 1975; Parsons, 1976; Sedberry and Musick, 1978; Schroeder, 1955; Snelgrove and Haedrich, 1985; Vasquez, 1991). It is sometimes reported as the dominant species in the deep waters catches of the Middle Atlantic Bight, specifically around the Norfolk Canyon (Wenner and Musick, 1977).

Given its widespread distribution and relatively high abundance, blue hake has been the subject of a considerable number of papers. However, most of the past publications have dealt with records of occurrence, comparative systematics (i.e. Musick et al., MS 1975; Small, 1981) biochemistry and physiology, perhaps because it is an easily accessible deepwater species (i.e. Josephson et al., 1975; Phleger, 1975; Somero and Seibenaller, 1979; Cohen, 1977; Graham et al., 1985). Relatively few studies have dealt with the life history or details of distribution. Iwamoto (1975) touched on the biology of the species, Wenner and Musick (1977) examined distribution and size composition of blue hake with respect to depth from the Middle Atlantic Bight (USA), Gordon and Duncan (1985) presented information on changes in abundance, length composition by depth and reproduction in the Rockall Trough west of Great Britain, Priede et al. (1994) looked at blue hake in situ off Britain and Magnusson (MS 1998, 2001) examined age, maturity and other biological parameters in Icelandic waters. Magnusson (MS 1998) noted the difficulty in aging blue hake and that, except for Gauldie et al. (1991), no other studies have been carried out on the structure of blue hake otoliths.

Parsons (1976) first described the distribution of this species in Canadian slope waters, our study area, but mainly in the context of its commercial potential. That study provided little detail on the distribution and biology. More recently, Vasquez (1991), based on limited samples, looked at morphometrics, diet and gonad condition of blue hake on the Flemish Cap.
The purpose of this study is to present a detailed description of the distribution and some aspects of the biology of blue hake along the continental slope off Canada (Fig. 1). We look at relative abundance and fish size in relation to depth, bottom temperature and latitude and compare our findings to areas south of our study and to populations in the eastern Atlantic. We also examine sex ratio in relation to depth. We compare the morphometrics and meristics of the Canadian slope fish to those described from the Atlantic and Pacific by Small (1981). Wenner and Musick (1977) posed several hypotheses about reproduction of this species (which is unknown), one being of a northern spawning migration (in our study area). A spatial examination of size of blue hake is used to investigate this hypothesis.

\section{Methods}

Information for this study was gathered from two sources: Canadian research surveys (1977-2000) and the commercial fishery (records of fishery observers from 1978-2000). Both covered a range of depths from near shore to about $1500 \mathrm{~m}$ (with limited sets to 2286 $\mathrm{m}$ ) over the much of the slope off Canada from latitude $41^{\circ} \mathrm{N}$, eastern Scotian Shelf and Grand Banks to $71^{\circ} \mathrm{N}$ in the Davis Strait. A line at $55^{\circ} \mathrm{N}$ was chosen to divide the study area north and south since it divided the Labrador Shelf from all areas south and it separated two heavily fished areas. Standardized catch per tow was compared north and south of $55^{\circ} \mathrm{N}$ in relation to depth and ambient (bottom) temperature.

For the depth analysis, intervals were set at $50 \mathrm{~m}$. Data from less than $500 \mathrm{~m}$ were grouped into a single interval because of the rarity of records at shallower depths, likewise for data greater than $1500 \mathrm{~m}$ because of limited sampling at those depths.

\section{Research surveys}

Catch standardized to the distance towed from Canadian trawl surveys was used to examine distribution of blue hake. Two type of trawl gears, Engel (1977-spring 1995, 26423 sets) and Campelen (autumn 1995 to 2000,8972 sets) were used in the analyses. Forty sets (1 371-2 $286 \mathrm{~m}$ ) were also taken with longlines, most beyond the depths covered by the trawl surveys. Survey and trawl characteristics are described in Doubleday (1981) and updated in Bishop (MS 1994). Average catch per tow (kg per standard tow) was calculated for depth intervals of $50 \mathrm{~m}$ for the two survey trawl gears (Fig. 2, lower left panel). Given that the catch rate for Engel and Campelen gear 


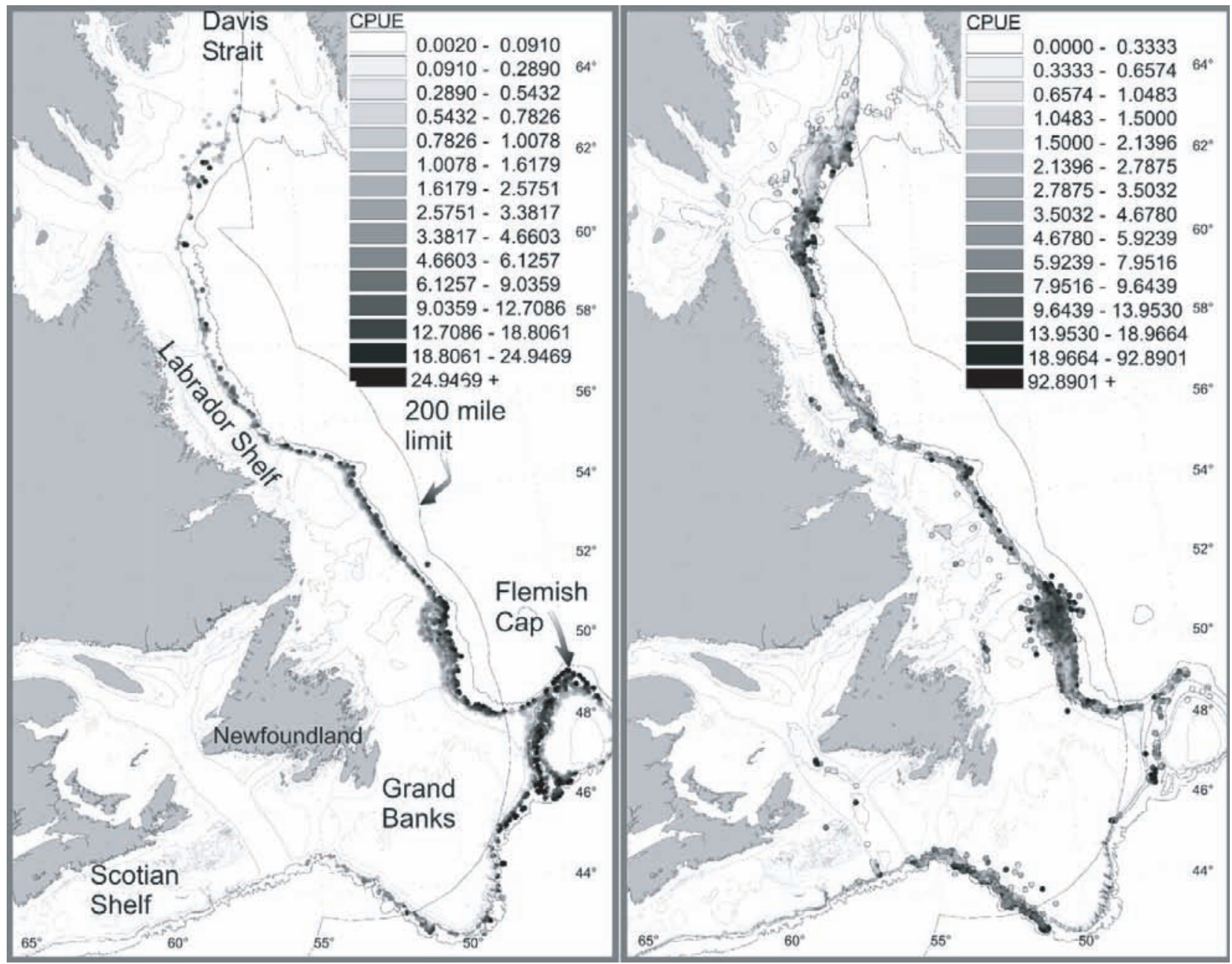

Fig. 1. Left Panel: Map of the study area showing blue hake distribution based on research surveys, 1977-2000 (CPUE $=$ kg per standard tow, lighter shades of grey depicts areas with lower catch rates of blue hake, darker areas depict higher catch rates). Right Panel: Blue hake distribution based on commercial fishing sets, 1978-2000 ((CPUE = kg per hour).

showed a similar trend and was of the same magnitude (refer to Fig. 2 lower left panel), data for the two gears were combined for subsequent analyses

\section{Commercial fishery}

Fisheries observers collect geo-referenced information on the catch, effort and other aspects of the fishing operation as specified in Kulka and Firth (MS 1987). Catch by species taken in the gear is included in the records along with latitude and longitude, depth and effort information. Over much of the study area, the commercial fisheries covered most of the shelf and the slope to a depth of $1700 \mathrm{~m}$. The extent of fishing varied annually, both in terms of depth and latitude, but at least in some years the observed effort covered most of the grounds beyond $200 \mathrm{~m}$ as well as a substantial part of the shallower areas. The eastern edge of the Grand Banks was undersampled in most years, because observers were not normally deployed to vessels fishing outside of Canada's 200-mile limit, except on the Flemish Cap. Under-sampling also occurred along the Scotian Shelf, where fishing rarely exceeded $450 \mathrm{~m}$, which is largely exclusive of the reported depth distribution of blue hake.

Given the variability in locations covered by the fisheries from year to year, data from all years were combined to provide an overview of the distribution. Catch rates were calculated as kg per hour for trawls, $\mathrm{kg}$ per 1000 hooks for longline and kg per 100 nets for gillnet. Average catch rate by depth showed a very similar trend for the three gears. Thus, data for the three gears were scaled to otter trawl catch per hour 

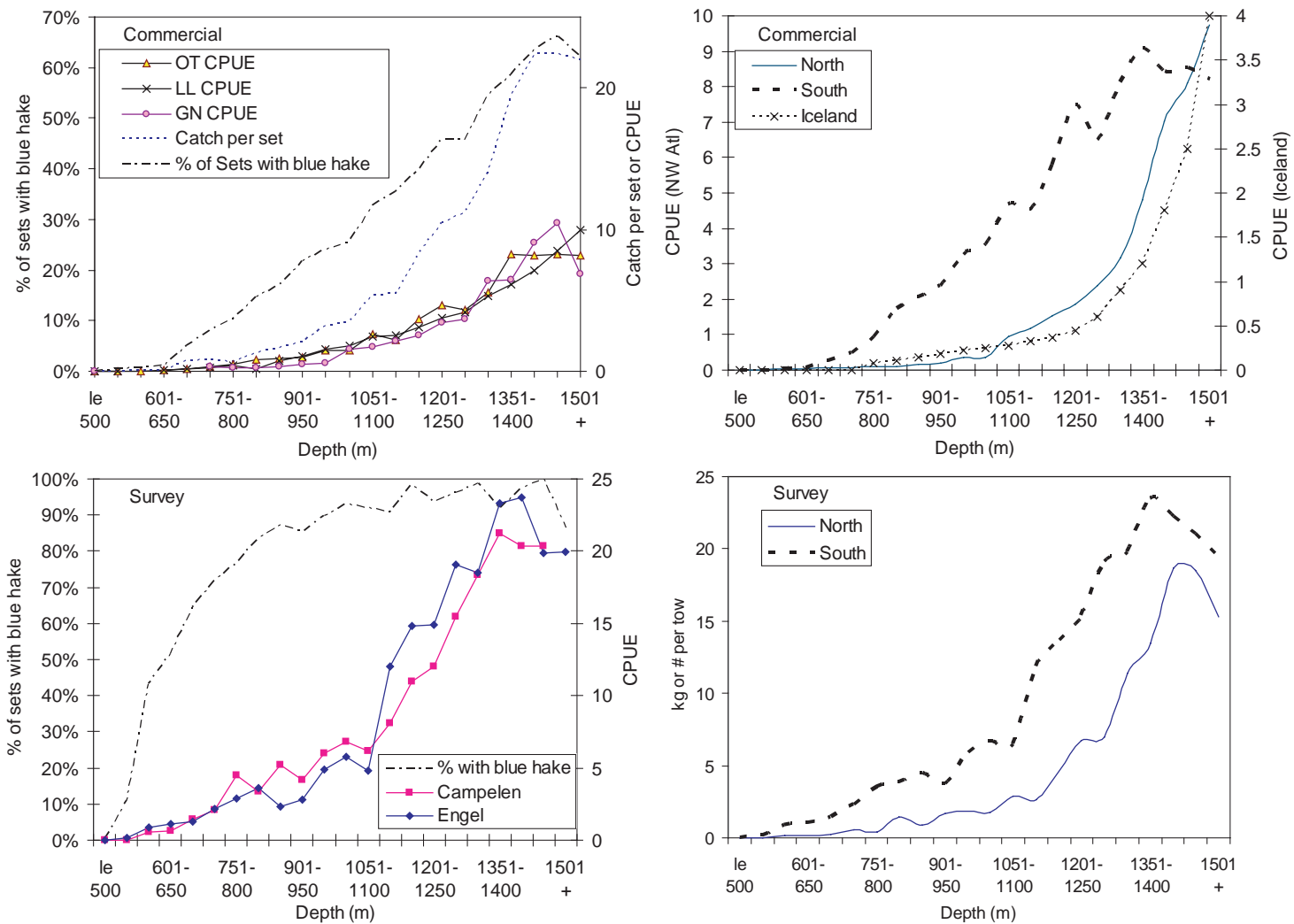

Fig. 2. Catch rates and number and percent of sets with blue hake by depth for commercial fishery and survey data. Upper left panel compares catch rates of the three commercial gears. CPUE (catch per unit effort) units are kg per hour for otter trawl (OT), per 1000 hooks for longline (LL) and per 100 nets for gillnet (GN). The lower left panel compares Engel and Campelen standardized kg per tow. The upper right panel compares catch rate (standardized to kg per hour) north of $55^{\circ} \mathrm{N} v s$ south of $55^{\circ} \mathrm{N}$ and catch rates reported by Magnusson (2001) off Iceland. The lower right panel shows standardized kg per tow for surveys north of $55^{\circ} \mathrm{N}$ and south of $55^{\circ} \mathrm{N}$.

and combined for subsequent analyses of catch rate at depth. As was done with the survey data, CPUE was compared north and south of $55^{\circ} \mathrm{N}$ in relation to depth and ambient (bottom) temperature.

\section{Mapping}

Potential mapping in SPANS (Spatial Analysis System, Anon, 1997) was used to map the distribution of the blue hake (depicting spatial variation in density) and to analyse distribution in relation to depth and bottom temperature. A description of how this mapping technique works can be found in Kulka (MS 1998). Bottom temperature values were not available with the commercial set data. Thus, contours of bottom temperature were created from long-term temperature mean data (1972-99) provided by MEDS (Marine Environments Data System, the Canadian repository for environmental marine data) using potential mapping. Fifteen strata of temperatures, each with equal areas, were created reflecting the range of temperatures observed. The geo-referenced sets were laid over this temperature surface and average catch rate was calculated within each temperature stratum.

\section{Morphometrics and meristics}

Blue hake were measured for total length by sex, 74569 fish from otter trawls and 867 from longlines. Data from surveys (1 770 fish measured) and commercial sources (72 791 measured) were combined to provide increased sample size and temporal coverage. The data spanned the entire study area from 1973-92, although not all years were represented and sampling was low in some years (refer to Table 1). All blue hake lengths were recorded as total length.

Length frequency data was initially plotted by gear type and year. Sets were weighted by the ratio of sample weight to set catch weight. Summary statistics 
were generated for both the individual sets and the summary frequencies. Mean size by sex was plotted against depth, mesh size, and latitude (north and south of $55^{\circ} \mathrm{N}$, corresponding to the two general areas fished). Sex ratios were examined by year, depth and latitude.

Collected during 1979-81, 2044 blue hake were measured for 17 morphometric characteristics and 18 meristic counts following Hubbs and Lagler (1970). These measurements and counts facilitated comparison of fish from this study with those from other parts of the world as reported by Small (1981). Analyses were conducted using S-Plus and SAS statistical packages. Univariate summaries for all continuous variables and count variables were recorded by sex. In addition, a two-sample t-test was used to test for differences between male and female character distributions. Equality of variance for the distributions was tested using an F-test. Further exploratory analysis consisted of correlation of all possible characters and plotting the bivariate relationship of each variable with standard length. In addition, linear regressions of head characters against standard length were conducted and compared between sexes. Variation in character distribution in relation to depth was also explored with box plots. Additional multivariate analyses to describe morphological and meristic variation in blue hake in relation to sex and depth were not successful because of missing cells. Finally, the results of the analyses from this study were compared with published values.

\section{Results}

From a total of 479682 commercial trawl fishing sets covering most of the banks and the outer shelf from the Scotian Shelf to the Davis Strait, 22828 sets yielded 686 tons of blue hake or $0.04 \%$ of the total observed catch of all species during that period. Similarly, 35395 research survey sets covering much of the shelf and part of the slope yielded 2275 sets (6.4\% of research survey sets) containing a total of 16 tons of blue hake.

\section{Distribution}

Sampling was sparse in three areas and there the distribution was under-represented. On the Scotian Shelf, only 64 survey sets were prosecuted at depths greater than $400 \mathrm{~m}$, but of these, 16 sets yielded blue hake at very low catch rates spread across the northeast portion of the shelf edge. These survey records are not clearly visible on Fig. 1 because the grey shade of the density surface area is very light, corresponding to low catch rates and thus are masked by the overlayed depth contours. On the eastern Grand Banks, the abrupt geographic truncation of samples at the 200-mile limit for the commercial data is due to the paucity of observations for fisheries occurring outside 200 miles (except on the Flemish Cap). However, the survey data demonstrate the abundance of blue hake in slope waters of the eastern Grand Banks, including the Flemish Pass between the Grand Banks and Flemish Cap (Fig. 1, left panel). As well, survey coverage north of $56^{\circ} \mathrm{N}$ was sparse but considerable commercial activity in that area confirmed the abundance of blue hake there (Fig. 1, right panel).

Both commercial fisheries and trawl survey data show that blue hake are distributed along the slope from the Scotian Shelf (the southern limit of sampling) to the mouth of Davis Strait $\left(65^{\circ} \mathrm{N}\right)$ and are relatively more abundant in deeper areas along the entire length of the slope, to the limit of the sampling (Fig. 1). The commercial fishery records also indicate that blue hake inhabit the deep (450-600 m) trenches on the shelf off Labrador and northeast Newfoundland and in the Laurentian Channel leading into the Gulf of St. Lawrence although sporadically and in low numbers (Fig. 1, right panel). As well, 11 mid-water sets with blue hake from the commercial fishery were recorded in the Laurentian Channel (depth of the gear ranged between 426 and $460 \mathrm{~m}$, about $50 \mathrm{~m}$ off the bottom) plus two sets on the Labrador Shelf (depth of gear 830 and $890 \mathrm{~m}$ ).

No blue hake were recorded north of the continental slope in Davis Strait. Of 38095 commercial fishing sets conducted between $65^{\circ} \mathrm{N}$ to $71^{\circ} \mathrm{N}$, mainly at depths beyond $300 \mathrm{~m}$, only one set yielded blue hake, at $66^{\circ} \mathrm{N} 58.5^{\circ} \mathrm{W}$, the northernmost record of blue hake west of Greenland.

Blue hake distribute at depths greater than most species in the survey area. Catches and number of sets containing blue hake from the commercial fisheries peaked at $1200 \mathrm{~m}$ whereas the combined weight of all species in commercial catches reached a maximum at less than $400 \mathrm{~m}$ (Fig. 3, lower panel). The reduction in catch of blue hake beyond $1200 \mathrm{~m}$ occurred because fishing effort declined rapidly beyond that depth. Percent of sets containing blue hake increased linearly from zero at $200 \mathrm{~m}$ to $70 \%$ at depths exceeding 1500 $\mathrm{m}$ (Fig. 3, upper panel). Blue hake as a percent of total catch also increased from near zero at $600 \mathrm{~m}$ peaking at $1.6 \%$ of the total catch at $1600 \mathrm{~m}$. (Fig. 3, 
TABLE 1. Inventory and summary statistics for blue hake length frequencies from otter trawl catches, $1973-92$. Data from research surveys and commercial fisheries are included. Size is recorded as total length (TL).

Otter Trawl

\begin{tabular}{|c|c|c|c|c|c|c|c|c|c|}
\hline Year & $\begin{array}{c}\text { No. } \\
\text { of Sets }\end{array}$ & $\begin{array}{l}\text { Mean } \\
\text { Sex }\end{array}$ & $\begin{array}{l}\text { Median } \\
(\mathrm{cm})\end{array}$ & $(\mathrm{cm})$ & St. Dev. & Min. Size & Max. Size & Mode & $\begin{array}{c}\text { No. } \\
\text { Measured }\end{array}$ \\
\hline \multirow[t]{3}{*}{1973} & 1 & Male & 27 & 23.5 & 7.44 & 15 & 40 & 23 & 15 \\
\hline & & Female & 34 & 31.5 & 9.84 & 22 & 51 & 37 & 17 \\
\hline & & Total & 31 & 30.5 & 9.47 & 15 & 51 & 37 & 32 \\
\hline \multirow[t]{3}{*}{1974} & 1 & Male & 21 & 21.5 & 5.13 & 15 & 25 & 15 & 3 \\
\hline & & Female & 22 & 21.5 & 9.00 & 13 & 31 & 13 & 3 \\
\hline & & Total & 21 & 21.5 & 6.59 & 13 & 31 & 22 & 6 \\
\hline \multirow[t]{3}{*}{1976} & 2 & Male & 25 & 21.5 & 6.76 & 12 & 38 & 19 & 38 \\
\hline & & Female & 28 & 26.5 & 5.11 & 19 & 36 & 27 & 27 \\
\hline & & Total & 26 & 25.5 & 6.38 & 12 & 38 & 19 & 65 \\
\hline \multirow{3}{*}{1978} & 13 & Male & 36 & 36.5 & 5.57 & 16 & 49 & 39 & 285 \\
\hline & & Female & 46 & 47.5 & 9.11 & 6 & 64 & 50 & 455 \\
\hline & & Total & 42 & 39.5 & 9.22 & 6 & 64 & 37 & 740 \\
\hline \multirow[t]{3}{*}{1979} & 38 & Male & 34 & 34.5 & 6.83 & 12 & 58 & 39 & 398 \\
\hline & & Female & 37 & 33.5 & 9.53 & 16 & 61 & 31 & 420 \\
\hline & & Total & 35 & 34.5 & 8.47 & 12 & 61 & 39 & 818 \\
\hline \multirow[t]{3}{*}{1980} & 21 & Male & 34 & 34.5 & 5.66 & 15 & 48 & 40 & 269 \\
\hline & & Female & 42 & 41.5 & 9.29 & 15 & 61 & 36 & 525 \\
\hline & & Total & 40 & 38.5 & 9.04 & 15 & 61 & 40 & 794 \\
\hline \multirow[t]{3}{*}{1981} & 405 & Male & 37 & 36.5 & 6.50 & 12 & 72 & 40 & 7320 \\
\hline & & Female & 44 & 44.5 & 9.75 & 7 & 69 & 50 & 13143 \\
\hline & & Total & 41 & 39.5 & 9.48 & 7 & 72 & 40 & 20463 \\
\hline \multirow[t]{3}{*}{1982} & 368 & Male & 42 & 40.5 & 7.40 & 21 & 68 & 40 & 5284 \\
\hline & & Female & 50 & 50.5 & 7.80 & 12 & 71 & 55 & 14236 \\
\hline & & Total & 48 & 47.5 & 8.50 & 12 & 71 & 42 & 19520 \\
\hline \multirow[t]{3}{*}{1983} & 100 & Male & 31 & 32.5 & 6.46 & 17 & 42 & 36 & 56 \\
\hline & & Female & 31 & 29.5 & 7.62 & 21 & 61 & 29 & 46 \\
\hline & & Total & 31 & 31.5 & 6.97 & 17 & 61 & 29 & 102 \\
\hline \multirow[t]{3}{*}{1984} & 19 & Male & 40 & 39.5 & 4.26 & 26 & 58 & 40 & 202 \\
\hline & & Female & 50 & 50.5 & 6.74 & 25 & 69 & 53 & 1357 \\
\hline & & Total & 49 & 49.5 & 7.41 & 25 & 69 & 53 & 1559 \\
\hline \multirow[t]{3}{*}{1985} & 40 & Male & 40 & 39.5 & 5.23 & 20 & 60 & 39 & 346 \\
\hline & & Female & 50 & 50.5 & 7.00 & 27 & 66 & 51 & 1224 \\
\hline & & Total & 48 & 48.5 & 7.74 & 20 & 66 & 51 & 1570 \\
\hline \multirow[t]{3}{*}{1986} & 201 & Male & 38 & 37.5 & 5.37 & 16 & 64 & 40 & 5387 \\
\hline & & Female & 48 & 49.5 & 8.23 & 22 & 73 & 52 & 17497 \\
\hline & & Total & 46 & 45.5 & 8.78 & 16 & 73 & 52 & 22884 \\
\hline \multirow[t]{3}{*}{1987} & 126 & Male & 36 & 36.5 & 5.21 & 14 & 59 & 37 & 2221 \\
\hline & & Female & 43 & 40.5 & 9.65 & 16 & 70 & 38 & 3767 \\
\hline & & Total & 41 & 37.5 & 8.92 & 14 & 70 & 38 & 5988 \\
\hline \multirow[t]{3}{*}{1992} & 8 & Male & 39 & 37.5 & 3.55 & 36 & 46 & 37 & 7 \\
\hline & & Female & 47 & 48.5 & 7.69 & 32 & 57 & 48 & 21 \\
\hline & & Total & 45 & 47.5 & 7.69 & 32 & 57 & 48 & 28 \\
\hline \multirow[t]{3}{*}{ Total } & 1343 & Male & 38 & 38.5 & 6.52 & 12 & 72 & 40 & 21831 \\
\hline & & Female & 47 & 48.5 & 8.99 & 6 & 73 & 55 & 52738 \\
\hline & & Total & 45 & 43.5 & 9.45 & 6 & 73 & 40 & 74569 \\
\hline
\end{tabular}


TABLE 1. (Continued). Inventory and summary statistics for blue hake length frequencies from otter trawl catches, 1973-92. Data from research surveys and commercial fisheries are included. Size is recorded as total length (TL).

Longline

\begin{tabular}{|c|c|c|c|c|c|c|c|c|c|}
\hline Year & $\begin{array}{c}\text { No. } \\
\text { of Sets }\end{array}$ & $\begin{array}{l}\text { Mean } \\
\text { Sex }\end{array}$ & $\begin{array}{l}\text { Median } \\
(\mathrm{cm})\end{array}$ & $(\mathrm{cm})$ & St. Dev. & Min. Size & Max. Size & Mode & $\begin{array}{c}\text { No. } \\
\text { Measured }\end{array}$ \\
\hline \multirow[t]{3}{*}{1973} & 87 & Male & 35 & 34.5 & 5.65 & 8 & 56 & 35 & 231 \\
\hline & & Female & 36 & 35.5 & 3.48 & 26 & 48 & 36 & 219 \\
\hline & & Total & 36 & 35.5 & 4.73 & 8 & 56 & 36 & 450 \\
\hline \multirow[t]{3}{*}{1987} & 32 & Male & 36 & 36.5 & 5.10 & 5 & 49 & 40 & 119 \\
\hline & & Female & 39 & 43.5 & 17.49 & 5 & 67 & 50 & 298 \\
\hline & & Total & 38 & 39.5 & 15.10 & 5 & 67 & 40 & 417 \\
\hline \multirow[t]{3}{*}{ Total } & 119 & Male & 36 & 35.5 & 5.47 & 5 & 56 & 36 & 350 \\
\hline & & Female & 38 & 37.5 & 13.55 & 5 & 67 & 36 & 517 \\
\hline & & Total & 37 & 36.5 & 11.08 & 5 & 67 & 36 & 867 \\
\hline
\end{tabular}

lower panel). Given that sampling was extremely low beyond $1400 \mathrm{~m}$ (1700 m maximum), it is not possible to determine exactly where abundance reached a maximum. At the greatest depths fished, the truncated catch curves seen in Fig. 3, indicating maximum or near maximum values at the greatest depths sampled suggests that neither the commercial effort nor survey sampling approach the maximum depths that blue hake inhabit. Twenty-five longline sets were prosecuted at depths beyond $2000 \mathrm{~m}$ and 10 of these deep sets, spread across the entire study area yielded blue hake out to $2286 \mathrm{~m}$, confirming their presence well beyond where most of the sampling occurred.

Catch rate (catch per tow for surveys and standardized catch rate based on otter trawl, longline and gillnet data for commercial data), reflecting local density of blue hake, increased exponentially with depth, peaking at about 1 400-1 $600 \mathrm{~m}$ (Fig. 3). However, the catch rate increased more slowly north of $55^{\circ} \mathrm{N}$ compared to the area to the south indicating a higher proportion of blue hake in shallower water to the south. The north and south commercial catch rates merged at $1500 \mathrm{~m}$ as the southern rate levelled off. Thus, north of $55^{\circ} \mathrm{N}$, blue hake were less abundant at all but the greatest depths sampled.

The average bottom temperature for sets with blue hake was $3.8^{\circ} \mathrm{C}$. Figure 4 , upper panel shows that $49 \%$ (north of $55^{\circ} \mathrm{N}$ ) and $35 \%$ (south of $55^{\circ} \mathrm{N}$ ) of the study area is associated with (time averaged) bottom temperatures less than $1.9^{\circ} \mathrm{C}$ whereas $98 \%$ of commercial fishery sets containing blue hake were associated with bottom temperatures exceeding $1.9^{\circ} \mathrm{C}$ (Fig. 4, middle panel). Commercial catch rate of blue hake peaked where bottom temperature was between 3.0 and $4.0^{\circ} \mathrm{C}$ in the south and 3.5 and $4.5^{\circ} \mathrm{C}$ in the north (Fig. 4, middle panel). All blue hake sets associated with bottom temperatures greater than $5^{\circ} \mathrm{C}$ occurred on the southwest slope of the Grand Banks and Scotian Shelf, the location of the some of the warmest bottom waters within the study area.

Compared to the commercial data, survey sets with blue hake spanned a similar but truncated range of bottom temperatures, between 1.4 and $8.7^{\circ} \mathrm{C}$ (Fig. 4 , lower panel). However, only $2 \%$ of the survey sets with blue hake were associated with bottom temperatures less than $3{ }^{\circ} \mathrm{C}$ or greater than $4.5^{\circ} \mathrm{C}$ and were virtually absent in less than $2^{\circ} \mathrm{C}$. The 16 sets from the Scotian Shelf containing blue hake were associated with an average bottom temperature of $3.8^{\circ} \mathrm{C}$, the same as the rest of the study area while sets without blue hake, at depths less than $400 \mathrm{~m}$, had an average bottom temperature of $13.9^{\circ} \mathrm{C}$.

Figure 5, top panel, based on survey data, shows that at depths greater than $550 \mathrm{~m}$, annual mean bottom temperature was about $2.0^{\circ} \mathrm{C}$ and seasonably variable. In the winter months, extensive areas of the inner shelf were less than $0.0^{\circ} \mathrm{C}$. Beyond $550 \mathrm{~m}$, average temperatures were warmer and seasonally consistent, between 3.0 and $4.0^{\circ} \mathrm{C}$, slightly cooler at greater depths. The greatest difference between areas north and south of $55^{\circ} \mathrm{N}$ occurs at $1000 \mathrm{~m}$ where on average, bottom temperatures are about $0.5^{\circ} \mathrm{C}$ warmer north 

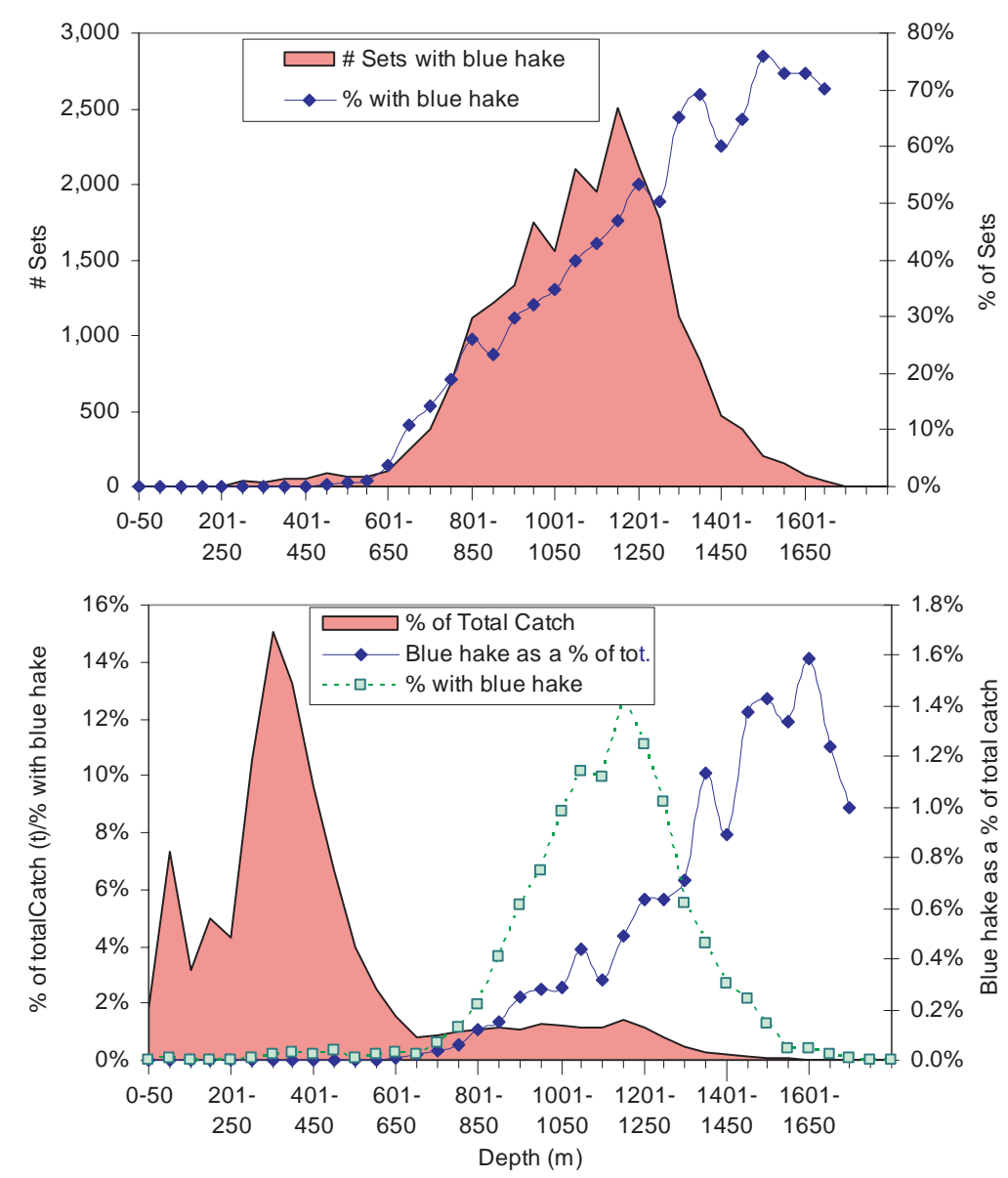

Fig. 3. Commercial catch and effort (observed otter trawl, longline and gillnet, 1978-2000) by depth. Upper panel shows number of sets with blue hake (shaded area) and percent of sets (of total commercial effort) with blue hake. Lower panel shows percent of total catch of all species by depth (shaded area scaled to left axis) in relation to blue hake as a percent of the total species catch weight (solid line scaled to right axis) and percent of sets with blue hake by depth (dashed line scaled to right axis).

of $55^{\circ} \mathrm{N}$. In contrast, temperatures at depth were much lower north of $65^{\circ} \mathrm{N}$, averaging about $2.0^{\circ} \mathrm{C}$ out to $750 \mathrm{~m}, 1.0^{\circ} \mathrm{C}$ between 750 and $1050 \mathrm{~m}$ then declining to $0^{\circ} \mathrm{C}$ at $1450 \mathrm{~m}$. No blue hake were caught in this area.

Figure 5, middle (north of $55^{\circ} \mathrm{N}$ ) and lower (south of $55^{\circ} \mathrm{N}$ ) panels comparing average temperatures for sets with blue hake to all sets shows that within the shallowest (and coldest) depths, less than $600 \mathrm{~m}$, blue hake selected the warmest available waters. Although average bottom temperature of survey sets was only about $2.0^{\circ} \mathrm{C}$ at depths less than $500 \mathrm{~m}$, sets containing blue hake have an associated temperature of about $3.8^{\circ} \mathrm{C}$. Beyond $600 \mathrm{~m}$, bottom temperature for sets with and without blue hake closely matched.

\section{Morphometrics and Meristics}

Blue hake length frequency distributions, summarized by gear across years indicate a distinct difference in size distribution between the sexes (Fig. 6 ). From otter trawl catches, males form a narrow range with a mean of $38 \mathrm{~cm}$ whereas females have a wider range of sizes with a mean size of $47 \mathrm{~cm}$. Annual means, medians, modes, minimum and maximum sizes and variation are reported in Table 1 and annual otter trawl frequencies (not illustrated) all showed a pattern similar to the cumulative graph (Fig. 6, upper 

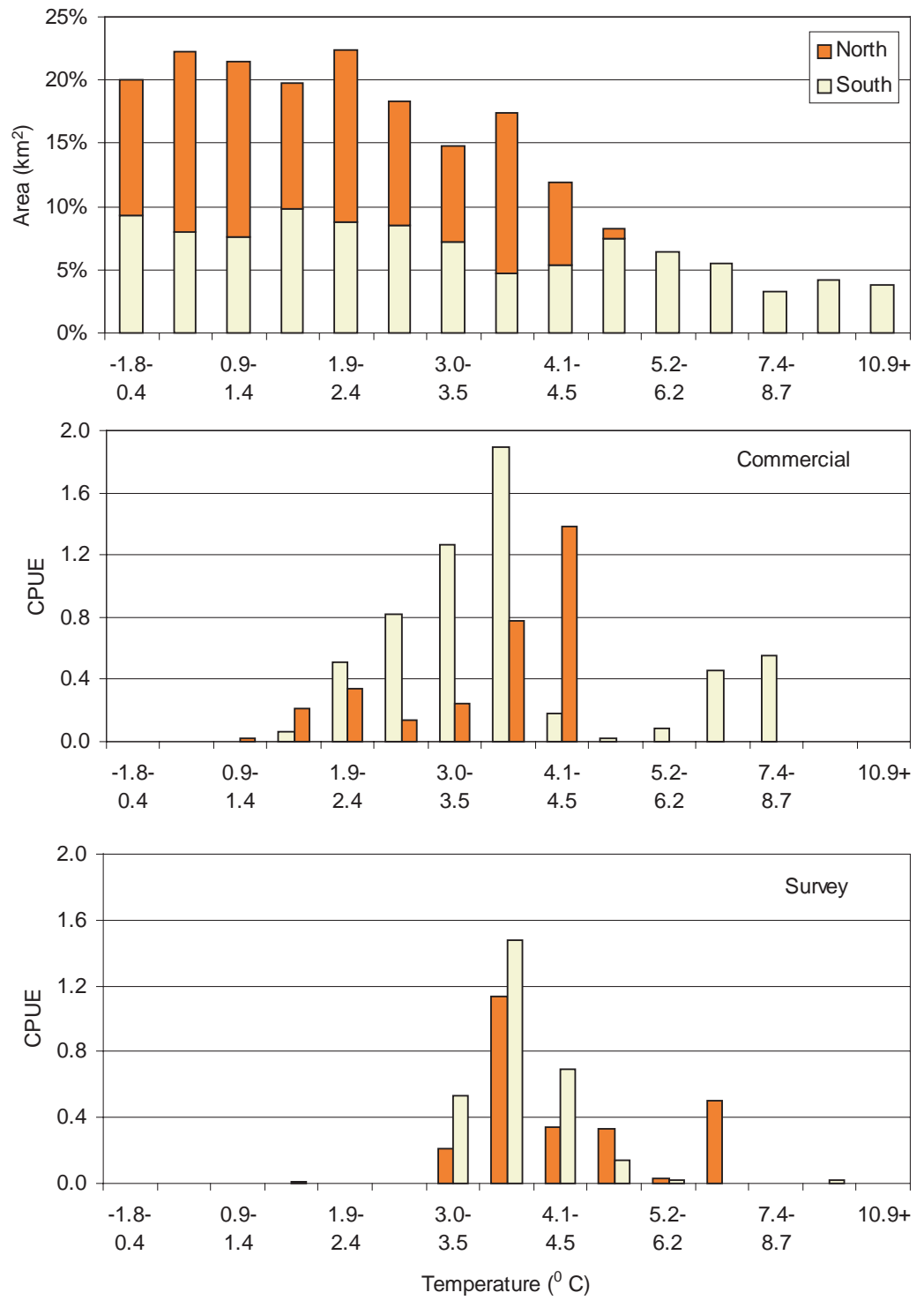

Fig. 4. Catch rate of blue hake with respect to bottom temperature. Upper Panel: Available habitat depicted as area of the ocean floor in $\mathrm{km}^{2}$ within bottom temperature strata, north and south of $55^{\circ} \mathrm{N}$ based on commercial fisheries data. Middle Panel: Commercial catch rate $(\mathrm{kg}$ per hr) of blue hake within temperature strata north and south of $55^{\circ} \mathrm{N}$. Lower Panel: Research survey catch rate (kg per tow) of blue hake within temperature strata north and south of $55^{\circ} \mathrm{N}$.

panel). Male distributions were unimodal in all years observed, the mean ranging from $36-40 \mathrm{~cm}$ (for years where sample size was sufficiently large) whereas female distributions were bimodal, with modes at 30 $40 \mathrm{~cm}$ and $50-55 \mathrm{~cm}$. The strength of each of the modes varied among years presumably due to variations in year class strengths.
Fish taken with longlines (mean of $36 \mathrm{~cm}$ for males, $38 \mathrm{~cm}$ for females) were smaller than those from otter trawl catches indicating selectivity for smaller individuals (Fig. 6, lower panel). The group of small fish, ranging from $5-17 \mathrm{~cm}$, was taken in two sets, one comprising 68 (61 less than $15 \mathrm{~cm}$ ) fish at $60^{\circ} 18^{\prime} \mathrm{N} 60^{\circ} 50^{\prime} \mathrm{W}(1280 \mathrm{~m})$, the other with 3 fish 

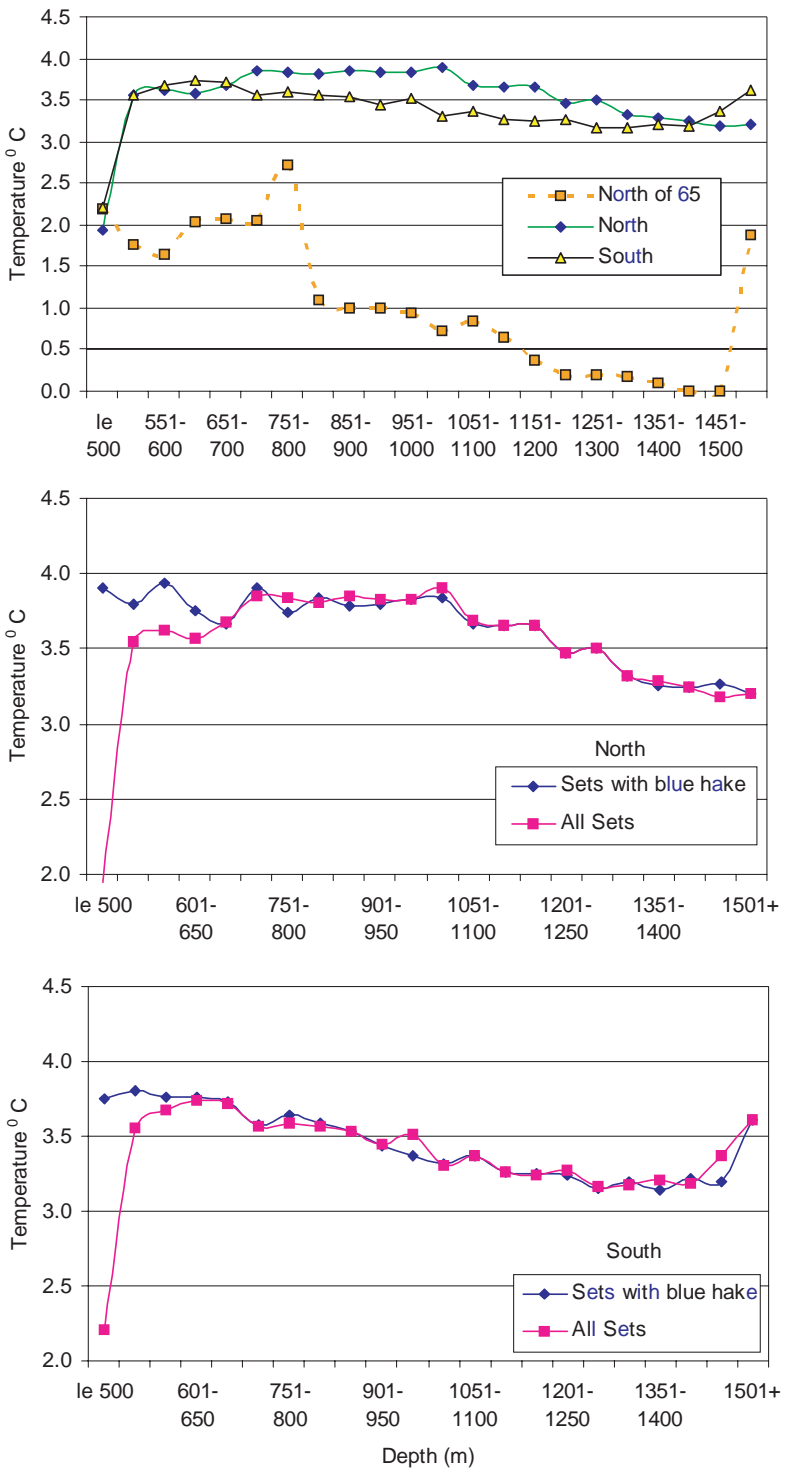

Fig. 5. Average temperature within depth strata for all research survey sets compared to only those sets with blue hake. The 500 refers to depths less than $500 \mathrm{~m}$.

at $61^{\circ} 10^{\prime} \mathrm{N} 60^{\circ} 40^{\prime} \mathrm{W}(915 \mathrm{~m})$, off northern Labrador. Fish less than $15 \mathrm{~cm}$ were also rarely encountered, in 29 otter trawl sets.

Mean size increased with depth but at different rates for males and females (Fig. 7). The pattern was fairly similar north and south of $55^{\circ} \mathrm{N}$ although maximum size peaked at a shallower depth to the south. Regardless of location, females exhibited a more pronounced change with depth, mean size increasing by $+10 \mathrm{~cm}(37-47 \mathrm{~cm})$ and median size by $+15 \mathrm{~cm}(33.5-48.5 \mathrm{~cm})$ between 700 and $950 \mathrm{~m}$. Mean size of males increased by $+4 \mathrm{~cm}(34-38 \mathrm{~cm})$ over this same depth range, with the median increasing by $+3 \mathrm{~cm}(34.5-37.5 \mathrm{~cm})$. At depths beyond $950 \mathrm{~m}$, both mean and median sizes remained relatively consistent for both sexes. Fish at comparable depth ranges tended to be larger in the southern area where observed means at depth were $+1 \mathrm{~cm}$ to $+12 \mathrm{~cm}$ larger for males and $+2 \mathrm{~cm}$ to $+11 \mathrm{~cm}$ larger for females.

Proportion of females also increased with depth (Fig. 8). Overall, values increased by approximately $35 \%$ (from $40 \%$ to $75 \%$ ) in the south and $35 \%$ (from $30 \%$ to $65 \%$ ) in the north between $500 \mathrm{~m}$ and about $1300 \mathrm{~m}$, levelling off at about $1000 \mathrm{~m}$. The trend is similar between areas, although the percentage of females was higher in the south.

Significant differences were observed between the sexes in all 16 of the morphometric characters investigated (Table 2). There were no significant differences observed between the sexes in any of the meristic characters. Female blue hake were significantly heavier and longer $(p<0.001)$ than male blue hake. Head length, interorbital width, upper jaw length and rostral length are also proportionally greater in females than in males.

Significant positive correlation between standard length and other linear measures shows that the morphometric differences between male and female blue hake are a consequence of scaling to body size. Overall, the larger size of females, in total length, standard length and whole weight, relative to males explains the differences observed between the sexes in each of the morphological characters. Furthermore, there were no significant differences between the slope and intercept of male and female blue hake regressions of head and gill filament measurements with standard length. Fig. 9 compares the relationship of gill filament length and head length to standard length for fish measured from our study area (sexes combined) to that reported by Small (1981).

There is no significant difference between the sexes in the relationship of rostral to standard length (females $y=5.7836+0.0114$ standard length, $r^{2}=$ 0.2864 , males $y=5.1816+0.012$ standard length, $r^{2}=$ 0.2653 ), but there was an apparent curvilinear relationship (Fig. 10). A log-transformed model also did not provide as good fit (log rostral length $=-0.2226$ $+0.4234 \log$ standard length, $\left.r^{2}=0.348\right)$ than a simple linear model (rostral length $=5.3853+0.0120$ standard length, $r^{2}=0.2888$ ). The lower end of the 

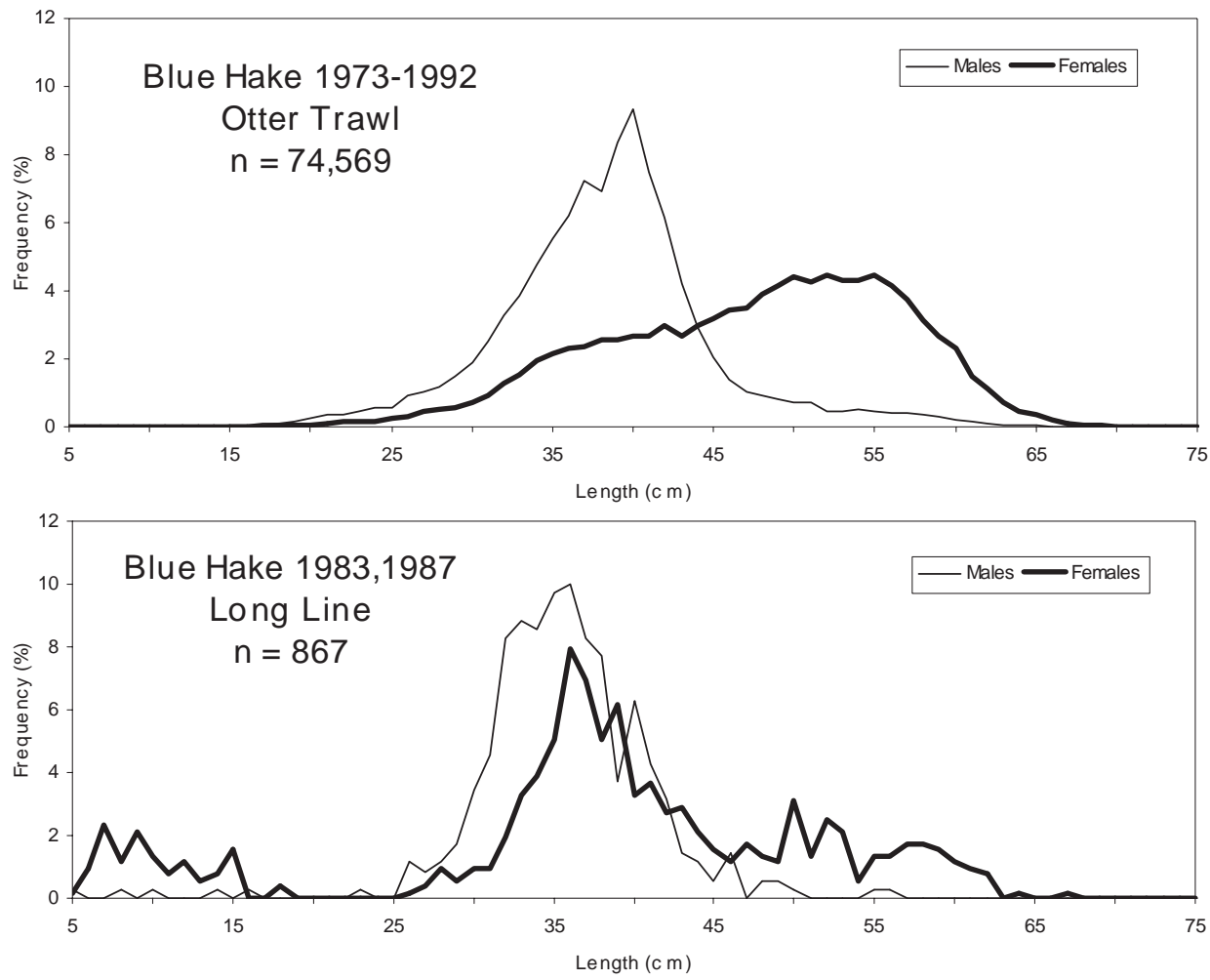

Fig. 6. Summary length frequencies of blue hake from otter trawls and longline gear. Lengths are recorded as total length.

curve is still poorly fitted even with the curvilinear model. However, a test of homogeneity of slopes for the rostrum/standard length relationship in small (less than $275 \mathrm{~mm} \mathrm{SL}$ ), medium (276-400 mm), and large (greater than $400 \mathrm{~mm}$ ) blue hake shows that the relationship between rostral and standard length changes with the size of blue hake (Table 3). Smaller fish have a proportionately larger rostrum although the relationship tends to level off for fish greater than $300 \mathrm{~mm}$.

Gonads as a proportion of total weight indicate that most blue hake sampled were immature. Average gonad weight as a percent of total weight was 0.35 $(\mathrm{SD}=0.26, \mathrm{n}=549)$ for females and $0.08(\mathrm{SD}=0.09$, $\mathrm{n}=547)$ indicating that most fish sampled contained very small, immature gonads. Although a few females were observed in ripening gonads, none in spawning or prespawning condition were observed.

Table 4 lists characteristics used to distinguish blue hake among different parts of the world. It shows that counts and proportions of the various measures in relation to standard length for our study area are similar to other areas of the world as reported by Small (1981). Fig. 11 compares the frequency count of gill filaments for our study area to the values reported by Small (1981) for the North Pacific and for all other parts of the world.

\section{Discussion}

\section{Distribution}

Our results, in conjunction with past studies, show that blue hake are continuously distributed (sometimes as the dominant species in the catches) along the slope from the Carolinas and possibly as far south as the Bahamas, north to southern Greenland and eastward to Iceland. To the south, the records of Goode and Beane (1895) between $33^{\circ} \mathrm{N}$ (off the Carolinas) and $42^{\circ} \mathrm{N}$ (southwest Scotian Shelf), Wenner and Musick, (1977) in the Middle Atlantic Bight, and Snelgrove and Haedrich (1985) along the southern slope of Georges Banks at $39^{\circ} \mathrm{N}$ indicate continuity in the distribution of blue hake in USA slope waters and as well, the Scotian Shelf (refer also to the description of distribution in the Introduction and Fig. 1 in Small 1981). Our study further demonstrates their continuity 

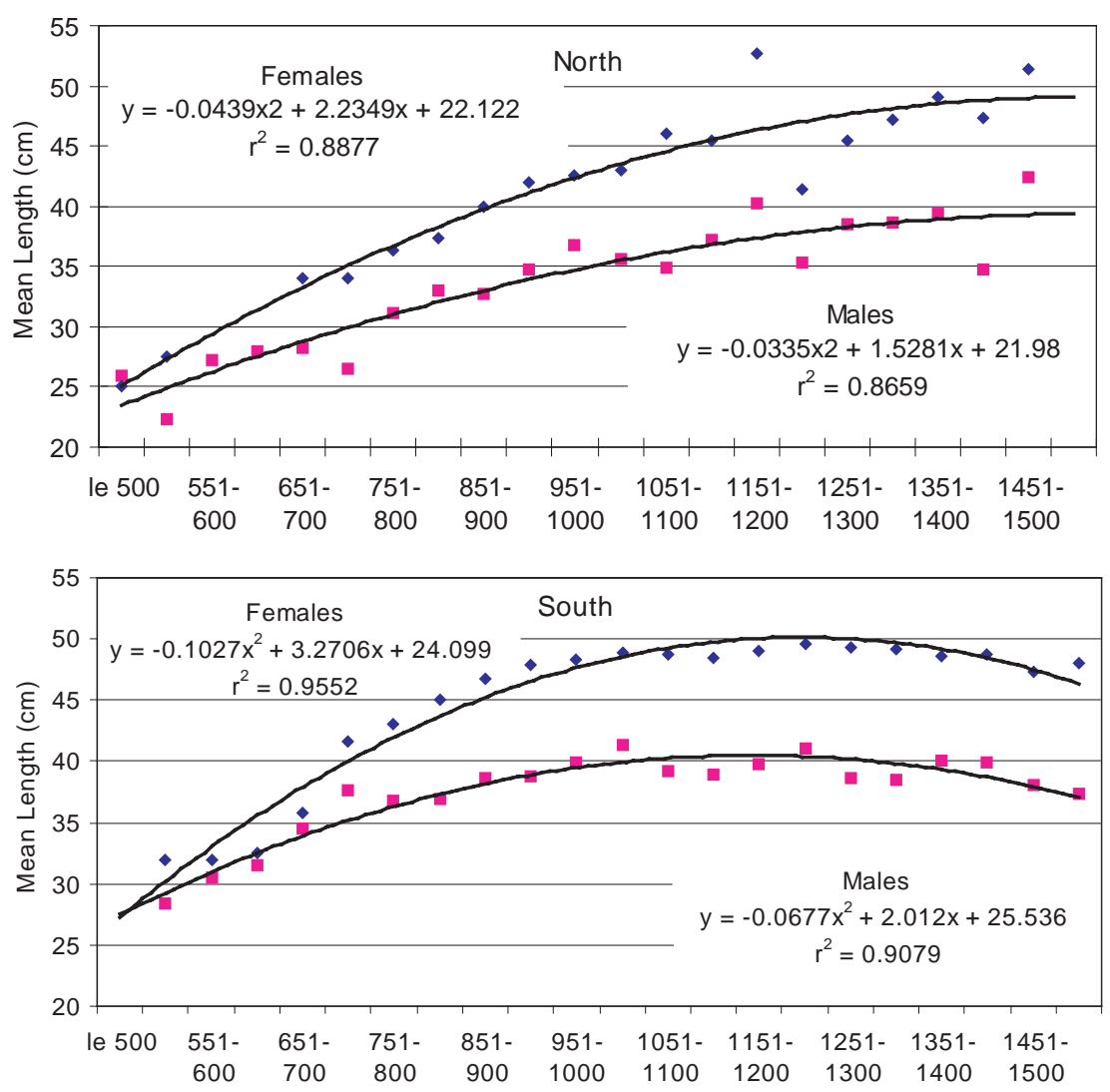

Fig. 7. Mean length of blue hake with respect to depth by sex, north and south of latitude $55^{\circ}$.

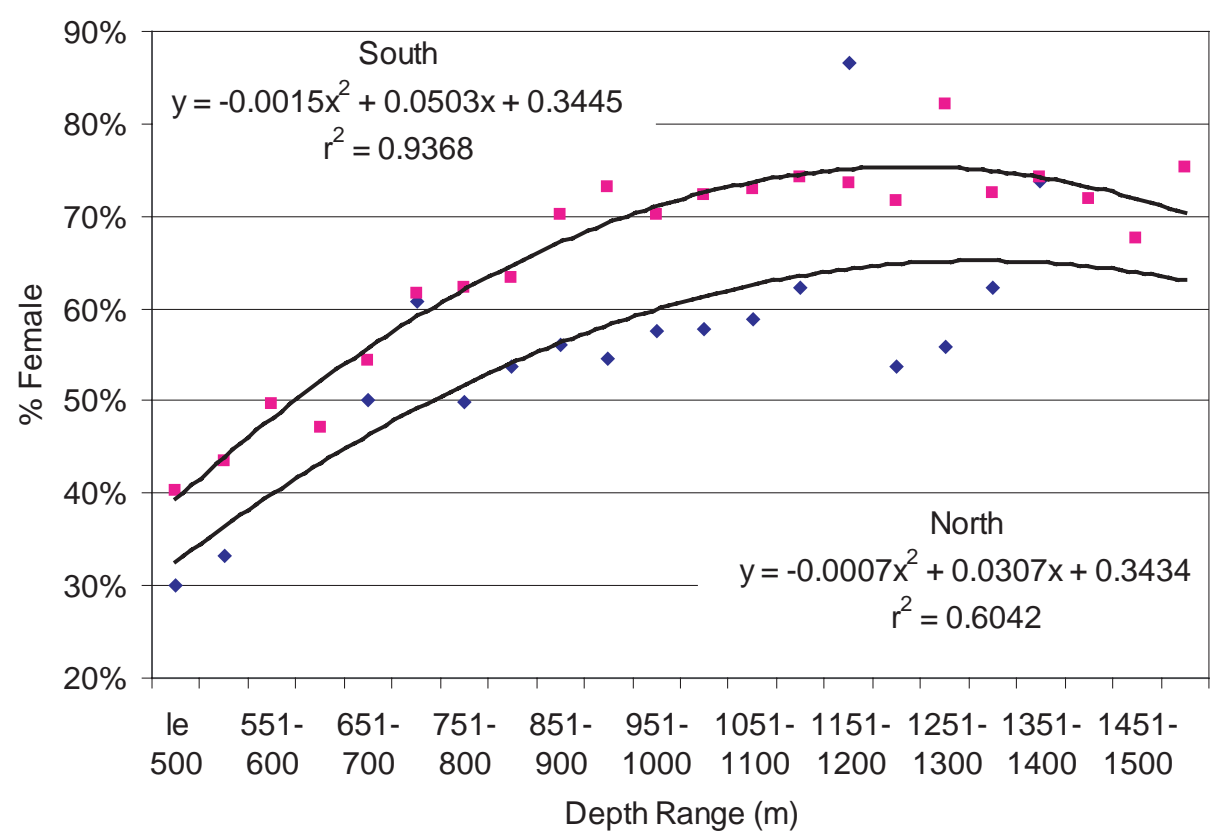

Fig. 8. Percent of female blue hake with respect to depth north and south of latitude $55^{\circ}$ and all areas combined. 
TABLE 2. T-tests comparison between sexes for various meristic characteristics. All measures are in mm, all weights in grams. See Hubbs and Lagler (1967) for a description of the variables. All "fin" variables refer to ray counts.

\begin{tabular}{|c|c|c|c|c|c|}
\hline Variable & Method & Variances & DF & t Value & $\operatorname{Pr}>|t|$ \\
\hline Anal fin & Pooled & Equal & 132 & 0.93 & 0.3544 \\
\hline Body depth & Pooled & Equal & 259 & 0.12 & 0.9076 \\
\hline Caecae weight & Pooled & Equal & 136 & 0.23 & 0.8213 \\
\hline Caudal fin & Pooled & Equal & 145 & -1.02 & 0.3103 \\
\hline Caudal peduncle & Pooled & Equal & 535 & -1.62 & 0.1056 \\
\hline Dorsal ray length & Pooled & Equal & 874 & 3.32 & 0.0009 \\
\hline $1^{\text {st }}$ Dorsal fin length & Pooled & Equal & 145 & 0.38 & 0.7066 \\
\hline $2^{\text {nd }}$ Dorsal fin length & Satterthwaite & Unequal & 139 & 0.68 & 0.4981 \\
\hline Gill filament length & Satterthwaite & Unequal & 828 & 6.52 & $<.0001$ \\
\hline Gill filaments & Pooled & Equal & 853 & 0.62 & 0.534 \\
\hline Girth & Satterthwaite & Unequal & 1067 & 5.45 & $<.0001$ \\
\hline Gonad weight & Satterthwaite & Unequal & 593 & 10.81 & $<.0001$ \\
\hline Left upper Gill raker & Pooled & Equal & 137 & -0.97 & 0.3324 \\
\hline Left lower Gill raker & Pooled & Equal & 135 & 1.62 & 0.1075 \\
\hline Gut weight & Satterthwaite & Unequal & 890 & 6.85 & $<.0001$ \\
\hline Head length & Satterthwaite & Unequal & 1364 & 6.82 & $<.0001$ \\
\hline Interorbital width & Satterthwaite & Unequal & 1289 & 6.09 & $<.0001$ \\
\hline Lateral pores & Pooled & Equal & 30 & -1.38 & 0.1768 \\
\hline Left pectoral fin & Pooled & Equal & 161 & -1.74 & 0.0837 \\
\hline Left pelvic fin & Satterthwaite & Unequal & 120 & 0.98 & 0.327 \\
\hline Liver weight & Satterthwaite & Unequal & 638 & 4.45 & $<.0001$ \\
\hline Orbit length & Satterthwaite & Unequal & 1398 & 5.68 & $<.0001$ \\
\hline Preanal length & Satterthwaite & Unequal & 1046 & 6.22 & $<.0001$ \\
\hline Predorsal length & Satterthwaite & Unequal & 455 & 0.04 & 0.9677 \\
\hline Prepectoral length & Pooled & Equal & 191 & 0.7 & 0.4848 \\
\hline Preventral length & Pooled & Equal & 182 & 0.32 & 0.7507 \\
\hline Right pectoral fin & Pooled & Equal & 158 & -0.84 & 0.4003 \\
\hline Right pelvic fin & Satterthwaite & Unequal & 105 & -2.27 & 0.025 \\
\hline Rostrum length & Satterthwaite & Unequal & 1457 & 6.86 & $<.0001$ \\
\hline Snout length & Satterthwaite & Unequal & 1352 & 9.43 & $<.0001$ \\
\hline Standard length & Satterthwaite & Unequal & 1305 & 5.33 & $<.0001$ \\
\hline Total length & Satterthwaite & Unequal & 1403 & 4.48 & $<.0001$ \\
\hline Upper jaw length & Satterthwaite & Unequal & 1272 & 6.64 & $<.0001$ \\
\hline Vertebrae & Pooled & Equal & 47 & -0.44 & 0.6634 \\
\hline Whole weight & Satterthwaite & Unequal & 918 & 6.92 & $<.0001$ \\
\hline
\end{tabular}

along the slope from the Scotian Shelf to west Greenland. The northern most record of blue hake in the northwest Atlantic is $66^{\circ} \mathrm{N} 58.5^{\circ} \mathrm{W}$ although most of our records occurred south of $55^{\circ} \mathrm{N}$. This corresponds with the northern limit east of Greenland as reported by Magusson (2001) off Iceland.

The abrupt truncation of commercial blue hake records at the 200-mile line off Greenland, the limit of our observed fishing activity suggests that they would be distributed eastward of that line, beyond our sampled area. No blue hake were recorded in the inventory of species from the south Greenland (1982-
96) surveys (Rätz, MS 1999) taking place east of our study area, but the maximum depth that they fished was only $400 \mathrm{~m}$. However, blue hake were commonly recorded in slope waters $\left(714-1495 \mathrm{~m},-0.1-4.7^{\circ} \mathrm{C}\right.$ ) east and west of Greenland (Ole Jorgenson, Danish Institute for Fisheries Research, Charlottenlund, Denmark, pers. comm.). Directly east of Greenland, blue hake are found in the Denmark Strait and Irminger Sea off Iceland (Haedrich and Krefft, 1978; Magnusson, MS 1998: Muus et al., 1990) to the slope waters of the Hebrides, west of Britain (Gordon and Duncan, 1985; Gordon et al. 1996), and on the midAtlantic Ridge (Magnusson, MS 1998, 2001). All 

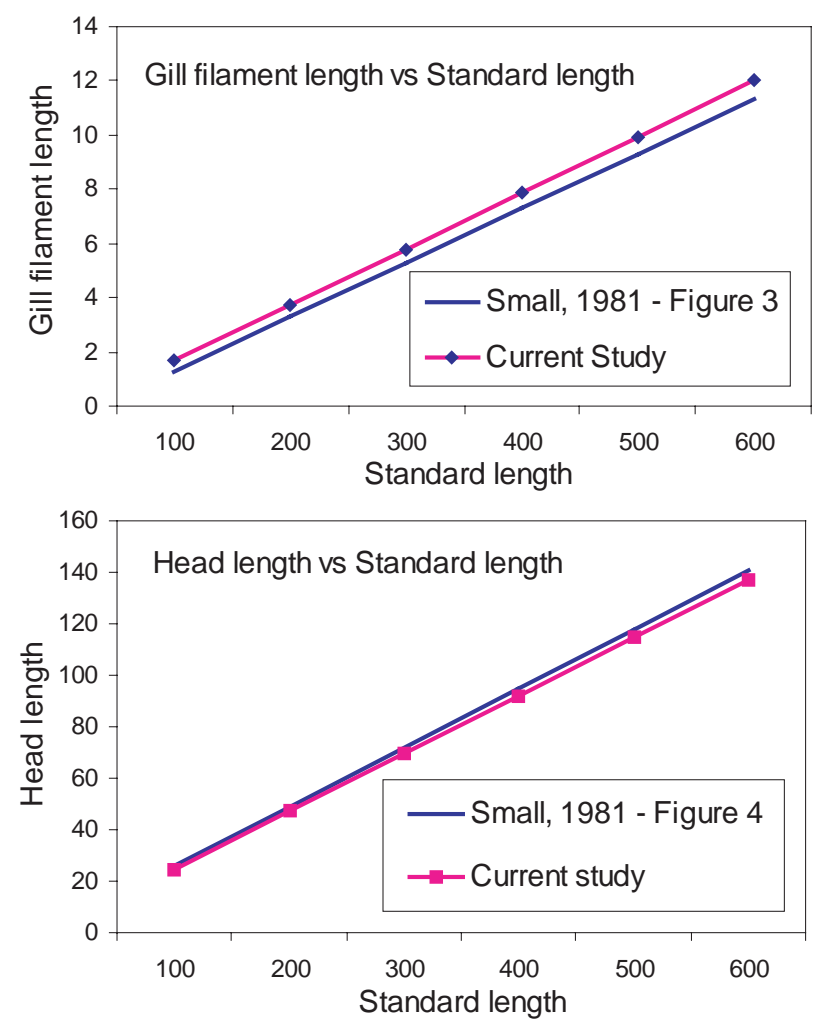

Fig. 9. Relationship between two key morphometrics gill filament length and head length with respect to standard length comparing the results of this study to Small (1981). Lengths are expressed in $\mathrm{mm}$.

these records together indicate that the distribution of northwest Atlantic blue hake is continuous with those in the eastern North Atlantic.

Previously, this species was not reported within semi-enclosed basins such as the Gulf of St. Lawrence (Parsons, 1976), Gulf of Maine (Bigelow and Schroeder, 1939, 1953), Caribbean and Gulf of Mexico (Bright, 1970; Bullis and Struhsaker, 1970), Gulf of Aden (Marshall and Bourne, 1964), the Mediterranean Sea, Red Sea, Sulu Sea or Sea of Japan (Iwamoto, 1975). However, we found that they sporadically inhabited the deepest basins on the Labrador Shelf and the Laurentian Channel. These records constitute their greatest known departure from slope waters.

The manner in which blue hake distribute with respect to depth in our study area varied with latitude but was similar compared to adjacent parts of the Atlantic. Blue hake in our area were found primarily beyond $500 \mathrm{~m}$ and their abundance peaked at or near the maximum depths sampled, at about 1600-1 700 m. The Goode and Bean (1895) records (Carolinas to Scotian Shelf) ranged from 556-2 $585 \mathrm{~m}$. Haedrich et al. (1980) from the slope of Georges Bank (adjacent to our study area) found blue hake to be among the top 10 species by weight in $653-3113 \mathrm{~m}$ and was dominant at 1300-1947 m, comparable to the range of maximum abundance observed in our study area. Further to the south in the Middle Atlantic Bight off the USA, blue hake were not as shallowly distributed as what we observed. Wenner and Musick (1977) showed that blue hake were not distributed at depths less than $1100 \mathrm{~m}$ with the exception of a single individual taken at $792 \mathrm{~m}$. They were common between 1300 and $2500 \mathrm{~m}$ and the catch rate peaked at $1800 \mathrm{~m}$.

The pattern of distribution south of $55^{\circ} \mathrm{N}$, including off the USA, contrasts with how blue hake distribute in the northern part of our study area and eastward to the Denmark Strait and Irminger Sea. Haedrich and Kreftt (1978) observed blue hake between 493 and $2058 \mathrm{~m}$ there but they reached their greatest numbers at shallower depths, at $975 \mathrm{~m}$, shallower than what we observed west of Greenland. Catch rate at depth described by Magnusson (2001) off Iceland was similar to what was observed in the northern part of our study area.

Progressively deeper minimum depth of occurrence southward suggests that the slope conditions off Greenland and the Labrador Shelf are different than the conditions farther to the south along Scotian Shelf and the continental slope off the USA. Haedrich and Kreftt (1978) cited the difference in the way that blue hake distributed with depth, north $v s$ south as an example of latitudinal submergence whereby widespread species such as blue hake tend to live at shallower depths at higher latitudes. However, they did not provide an explanation for this phenomenon. Since blue hake are associated with a fairly narrow range of bottom temperatures, it appears that differences in temperature conditions in slope waters in the northwest Atlantic influences how blue hake distribute.

Virtually no blue hake inhabited the area north of $65^{\circ} \mathrm{N}$ where although depths exceeded $500 \mathrm{~m}$, bottom temperatures were almost exclusively less than $2{ }^{\circ} \mathrm{C}$. East of the northern part of our study area, Magnusson (MS 1998) in the Demark Strait and Irminger Sea noted a temperature range of $3.4-5.2^{\circ} \mathrm{C}$ for blue hake. Haedrich and Kreftt (1978) over a similar range observed blue hake in bottom 

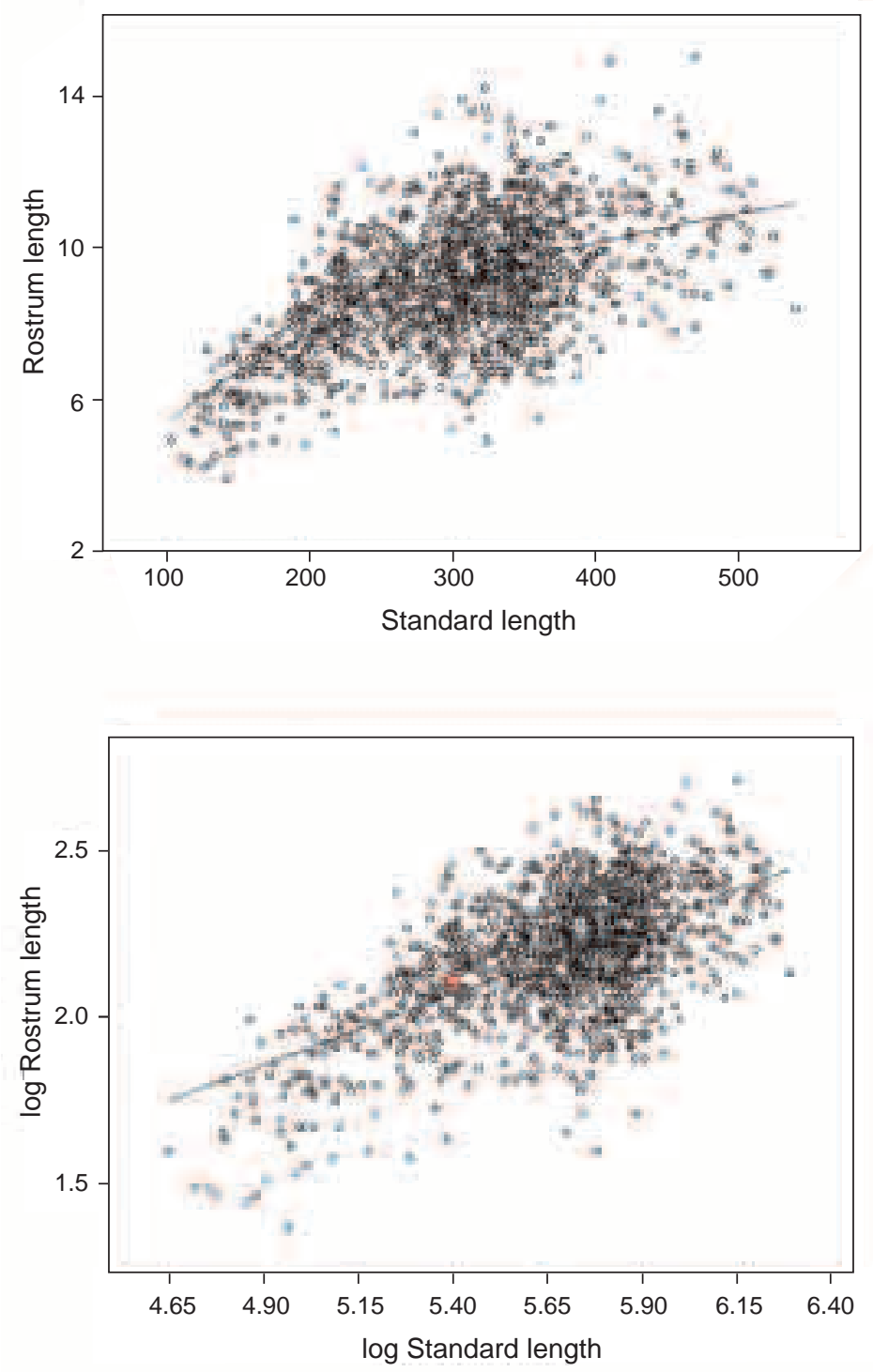

Fig. 10. Bivariate relationship of rostrum length with standard length. Lengths are expressed in $\mathrm{mm}$.

temperatures of $0.1-3.4^{\circ} \mathrm{C}$ but they did not provide details of the distribution with respect to that range of temperatures. To the south on the Scotian Shelf, shelf waters are more temperate and warmer than the adjacent slope waters, It appears that the deeper minimum depth that blue hake inhabit there $(649 \mathrm{~m})$ compared to areas north is a result of warm bottom shelf and upper slope water restricting blue hake to deeper, colder waters. Although we did occasionally record some fish in temperatures as warm as $8.7^{\circ} \mathrm{C}$ in our study area, the large majority were found at less than $4.5^{\circ} \mathrm{C}$. Off the Middle Atlantic Bight, Wenner and Musick (1977) reported temperatures between 2.9 and $4.2^{\circ} \mathrm{C}$ at depths greater than $1100 \mathrm{~m}$. Temperatures at depth less than $1100 \mathrm{~m}$ in the Middle Atlantic Bight were even warmer than those on the Scotian Shelf, hence the lack of shallow (500-1 $100 \mathrm{~m}$ ) records there.

\section{Morphometrics and Meristics}

Consistent with other studies (Magnusson MS 1998 and 2001; Wenner and Musick 1977), female blue hake grow to a larger size than males. Mean size of blue hake in our study area $(38.0 \mathrm{~cm}$ for males and $47.0 \mathrm{~cm}$ ) was observed to be somewhat larger than that reported by Magnusson (2001) off Iceland (31.5 
TABLE 3. Results of a test of homogeneity of slopes of the rostrum/standard length relationship in small (less than 275 $\mathrm{mm} \mathrm{SL}$ ), medium (276-400 $\mathrm{mm}$ ), and large (greater than $400 \mathrm{~mm}$ ) blue hake.

\begin{tabular}{|c|c|c|c|c|c|}
\hline Source & DF & Type I SS & Mean Square & F Value & $\operatorname{Pr}>\mathrm{F}$ \\
\hline Standard length & 1 & 1115.806591 & 1115.806591 & 577.84 & $<.0001$ \\
\hline Size group & 2 & 31.187876 & 15.593938 & 8.08 & 0.0003 \\
\hline Standard length* group & 2 & 142.152828 & 71.076414 & 36.81 & $<.0001$ \\
\hline Parameter & & Estimate & Error & t Value & $\operatorname{Pr}>|t|$ \\
\hline Standard length: Group 1 (smallest) & & 0.02600008 & 0.00164262 & 15.83 & $<.0001$ \\
\hline Standard length: Group 2 (med. fish) & & 0.00793892 & 0.00161142 & 4.93 & $<.0001$ \\
\hline Standard length: Group 3 (lg. fish) & & 0.00266231 & 0.00391314 & 0.68 & 0.4964 \\
\hline
\end{tabular}

TABLE 4. Summary of blue hake morphometrics from: Table 2. Small, G. J., 1981. A review of the bathyal fish genus Antimora (Moridae: Gadiformes). Proc. Cal. Acad. Sci., 42: 341-348 compared to the present study. SD is standard deviation.

\begin{tabular}{|c|c|c|c|c|c|c|c|c|c|c|}
\hline & $\begin{array}{c}\text { N. } \\
\text { Pacific }\end{array}$ & SD & $\begin{array}{c}\text { SE. } \\
\text { Pacific }\end{array}$ & $\begin{array}{c}\text { S. } \\
\text { SD }\end{array}$ & $\begin{array}{c}\text { N. } \\
\text { Ocean }\end{array}$ & SD & Atlantic & $\mathrm{SD}$ & Study & $\begin{array}{c}\text { Current } \\
\text { SD }\end{array}$ \\
\hline Snout length & 11.9 & 0.86 & 11.8 & 1.33 & 12.6 & 1.53 & 12.7 & 1.16 & 13.22 & 1.34 \\
\hline Predorsal length & 3.9 & 1.47 & 3.7 & 0.2 & 3.9 & 0.2 & 3.7 & 0.17 & 3.97 & 0.33 \\
\hline Maxillary length & 7.1 & 0.36 & 6.9 & 0.5 & 7.4 & 0.49 & 7.2 & 0.38 & & \\
\hline First dorsal fin ray length & 5.9 & 1.43 & 7.1 & 1.58 & 6.1 & 1.4 & 5.1 & 1.45 & 4.46 & 0.88 \\
\hline Eye diameter & 15 & 1.2 & 15.3 & 1.34 & 16.2 & 1.36 & 16 & 1.42 & 15.9 & 1.76 \\
\hline Interorbital width & 17.6 & 1.45 & 18.6 & 1.61 & 18.3 & 1.64 & 15.5 & 1.56 & 19.13 & 2.47 \\
\hline Longest gill raker length & 73.4 & 14.07 & & & 103 & 16 & 76.9 & & & \\
\hline Number of vertebra & 59.1 & 0.86 & 58.8 & 0.96 & 59.6 & 1.02 & 59.8 & 1.26 & 57.27 & 1.68 \\
\hline Number of gill rakers & 16.5 & 1.93 & 16.2 & 1.29 & 16 & 1.54 & 16.6 & 2.11 & & \\
\hline Number of anal fin rays & 40.6 & 1.4 & 39.3 & 1.39 & 40 & 1.7 & 41.9 & 1.56 & 42.65 & 3.74 \\
\hline Number of dorsal fin rays & 52.4 & 1.15 & 51.7 & 1.37 & 53.2 & 1.45 & 53.8 & 1.45 & 54.48 & 2.02 \\
\hline
\end{tabular}

Lengths are represented as ratio of standard length to size of part Regression of head length on standard length $y=0.23 x+2.9432$ Regression of gill filament length on standard length, $y=0.02 x-0.7$

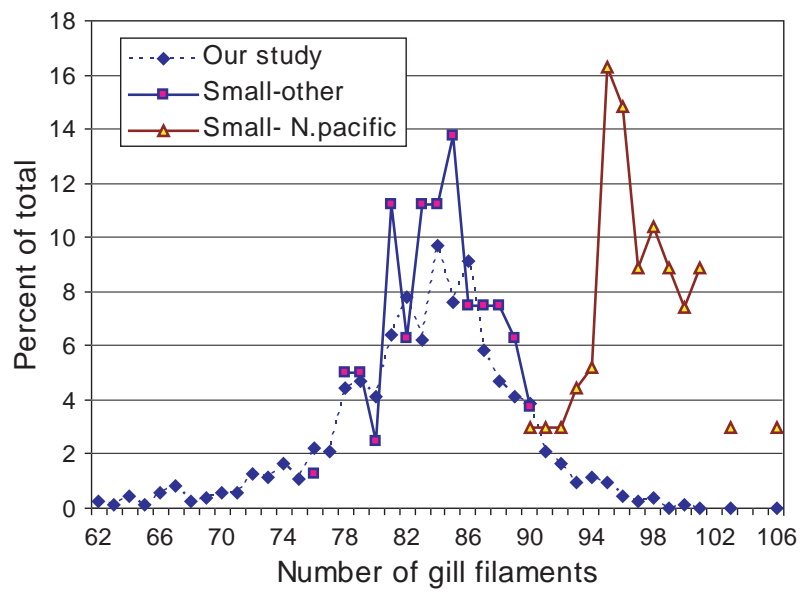

Fig. 11. Frequency distribution as a percent of total number of gill filaments measured for our study area compared to those reported by Small (1981) for the North Pacific and other parts of the world. $\mathrm{cm}$ for males and $42.9 \mathrm{~cm}$ for females) at depths less than $1500 \mathrm{~m}$. However, these differences could be gear related such as difference in mesh size used. The frequency distribution reported by Wenner and Musick (1977) in 1100 to $2000 \mathrm{~m}$ off the Middle Atlantic Bight, a similar range of depths to our study was very similar to what we observed. Fish sizes from other studies were based on small sample size and usually not sexed, but mostly fell within the mid to upper range of sizes that we reported.

Small (1981) noted that blue hake less than 10 $\mathrm{cm} \mathrm{SL}$ are rare. None were found in the published records. Of 867 fish captured in longline gear in our area, we encountered 68 fish in two sets in the range of 5-17 cm TL (4.5-15.5 cm SL), 37 of which were less than $10 \mathrm{~cm} \mathrm{TL}(9.1 \mathrm{~cm} \mathrm{SL})$. These records occurred at 1245 and $915 \mathrm{~m}$ (not in the shallowest 
depths where average size was lowest, as discussed below). Magnusson (MS 1998) also noted off Iceland that the average depth where the smallest blue hake were taken was $1289 \mathrm{~m}$. Only two fish less than 10 $\mathrm{cm}$ in our study area from a total of 74569 fish were captured in otter trawl gear. These records represent amongst the smallest blue hake observed worldwide and according to the limited aging work done by Magnusson (MS 1998), the fish less than $15 \mathrm{~cm}$ would probably be 1-3 years old. Wenner and Musick (1977) did not encounter fish less than $17 \mathrm{~cm} \mathrm{SL}$, rarely less than $20 \mathrm{~cm}$ in the Middle Atlantic Bight. Similarly, Gordon and Duncan (1985) in the Rockall Trough did not report fish less than $20 \mathrm{~cm}$. However, a limited number of blue hake less than $10 \mathrm{~cm}$ were observed in the Porcupine Seabight west of Ireland (1975-92) and in 1999, at $1000 \mathrm{~m}$ in the Rockall Trough, five hauls yielded a substantial number of fish in the range of 8-19 cm SL (pers. comm., John D.M. Gordon Scottish Association for Marine Science, Oban, PA37 1QA UK). One other occurrence of small fish came from a trawl set from the Bear Seamount off Georges Bank in 2000 that yielded six individuals ranging from 12.5-31 cm SL. (Jon A. Moore, Florida Atlantic University, Jupiter, Florida, USA, pers. comm.).

Smaller (and presumably younger) fish occurred at shallower depths in our study area, average size increasing from about $27 \mathrm{~cm}$ at the shallowest depths levelling off at about $45 \mathrm{~cm}$ at the deepest depths sampled, very similar to what Wenner and Musick (1977) reported from the Middle Atlantic Bight. As well, fish at comparable depth ranges tended to be larger to the south within our study area. In the Rockall Trough, Gordon and Duncan (1985) noted that juveniles were confined to the mid slope, adults to lower slope and continental rise. Haedrich and Krefft (1978) in the Irminger Sea observed 23-60 cm fish at $643-661 \mathrm{~m}$, similar to what we observed. Polloni et al. (1979) noted that mean weight of fish tends to increase with depth and this observation is also consistent with the pattern observed in our area. None of these analyses differentiated between the sexes. We found that males and females were about the same size at the shallowest depths but females exhibited a more pronounced increase in size with depth suggesting sexually dimorphic growth as well as older fish of both sexes distributed at greater depths.

Larger female body mass is associated with larger girth, gut, gonad and liver weight of females and this is consistent with previous studies (Wenner and Musick, 1977; Small 1981). Head length, interorbital width, upper jaw length and rostral length are proportionally greater in females than in males. Significant positive correlation between standard length and other linear measures shows that the morphometric differences between male and female blue hake are a consequence of scaling to body size. Overall, the larger size of females, in total length, standard length and whole weight, relative to males explains the differences observed between the sexes in each of the morphological characters.

Larger blue hake of both sexes were found in deeper waters, consequently there is an overall trend for correlated morphological characters to increase with increasing depth. This pattern is based on the prevalence of female blue hake, which are larger than males, and larger males being captured in deeper waters. When standardized, by length and sex, there is no significant variation in character variation with depth for blue hake. Previous studies have not examined morphological differences with respect to depth but did observe that the average weight of blue hake increased with increasing depth (Polloni et al., 1979; Snelgrove and Haedrich, 1985; Wenner and Musick, 1977).

A distinguishing characteristic of the genus Antimora is its distinct rostrum. While there was no significant difference between the sexes in the relationship of rostral to standard length, smaller fish have a proportionately larger rostrum. As the fish grows, rostral growth increasingly slows in relationship to overall growth levelling off for fish greater than $300 \mathrm{~mm}$.

Deceleration in rostral growth may relate to the onset of maturity. However, consistent with our findings, other studies note that blue hake sampled are largely immature. Magnusson (MS 1998) provides the most comprehensive analysis of gonad condition. From samples gathered mainly in June and July off Iceland, he noted that while most fish were immature, some maturing fish and a few spent fish were observed in March and July. No fish in spawning condition were observed. Those records of spent fish are the only evidence of (past) reproductive activity for this species since spawning fish, eggs or larvae have never been observed.

Small, (1981) divided the genus Antimora into two species, A. microlepis in the North Pacific and $A$. rostrata in the rest of the world based primarily on the number of gill filaments, the ratio of gill filament 
length to standard length and head length to standard length. His morphometric relationships for the Atlantic closely matched our results but the count of gill filaments for our area (62-100) overlaps the range counts for both $A$. rostrata (76-90) and A. microlepis (90-106) reported by Small (1981). Although the distribution of the counts of this characteristic form partially separated modes, near separate ranges as reported by Small (1981) cannot be used to distinguish the two species. He also reported small differences in a number of other characteristics. The various morphometric relationships reported by Small (1981) in his Table 2 were similar to what we found although our average interorbital width as a ratio of standard length is also closer to the Pacific and South Ocean values. The only characteristic that clearly distinguishes North Pacific Antimora from those in others locations is length of gill filament in relation to head length.

\section{Conclusions}

Given its global distribution, blue hake ranks among the most commonly encountered of marine fish. Along much of the slope of eastern North America, around southern Greenland, and further into the northeast Atlantic, it forms a continuous distribution. We have shown that blue hake occur within a narrow range of temperatures and at different latitudes, blue hake distribute differently in relation to depth probably a result of local slope conditions.

While our study provides for a much more detailed view of the distribution of the adult individuals off eastern Canada, like past studies, it provides little insight into the early life history of blue hake. Wenner and Musick (1977) proposed as one of five hypotheses that for the Atlantic, blue hake spawn in the northern part of its range, our study area. We have shown that young fish do occur the northern part of their range in the western Atlantic although numbers caught were few. Otherwise, our analyses did not support this hypothesis. We found no evidence of eggs, larvae, or spawning fish, and individuals with maturing gonads were rare. A few females with ripening gonads were observed, but none in spawning or prespawning condition. As we have defined the northern limit of the distribution of blue hake at the mouth of Davis Strait, it would seem unlikely that spawning would take place north of that point. Thus, Wenner and Musick's (1977) hypothesis is not supported by our study and the questions related to the early life history of this species remain unanswered.
Why the reproductive phase of blue hake has not been observed and why small fish are rarely observed is clearly a sampling issue. The presence of small fish from the longlines (albeit based on very limited samples) compared to the trawls fishing the same area suggests a catchability issue with the otter trawl gear, which is what most world records are based on. In our study area, sampling only occurs as deep as 1700 $\mathrm{m}$ (with the exception of a few deeper longline sets) where the density of blue hake is likely reaching its peak. Thus, we have missed at least half of the distribution. Given that we have defined the shallow part of the distribution and the size of fish was observed to increase with depth, it seems likely that spawning could occur beyond depths that we sampled, perhaps in the mid-ocean although no eggs and larvae of this species have been reported from great depths here or in other parts of the world.

Blue hake were amalgamated into a single species by Schroeder (1940), but Small (1981) has subsequently divided the genus into two species. Our counts of the key meristic characteristic used to by Small (1981) to separate the species overlapped significantly with the North Pacific counts. For fish this similar, genetic work will be required to determine if they are separate entities at the species level. Thus, taxonomy of this species remains open for discussion.

We have presented information from commercial catches showing that they are a common by-catch in deep-water fisheries. However, in terms of commercial potential (the question posed by Parsons, 1976), blue hake has not been the target of a directed commercial fishery in the northwest Atlantic slope or any part of its range. Logbook and observer records from deepwater fisheries off eastern Canada indicate that it is sometimes retained. Estimated removals of blue hake as by-catch from our study area based on 23 years of direct observations is 3500 tons or 150 tons per year average, diminishing in recent years due to a reduction in deep water fisheries. Blue hake do not concentrate in sufficiently high densities to warrant directed commercial exploitation and its peak densities are generally located at depths beyond $1500 \mathrm{~m}$ where trawling or longlining activities are marginal. Thus, it will remain of limited commercial value.

\section{Acknowledgements}

We wish to thank the fishery observers and Fisheries and Oceans research staff who have 
recorded, collected and measured many blue hake over the years.

\section{References}

ANON. 1997. SPANS 7.0 Prospector. TYDAC Research Inc. BARNARD, K. H. 1925. Descriptions of new species of marine fishes from South Africa. Ann. and magazine of Nat. Hist. Ser., 9, 15: 498-504.

BIGELOW, H. B., and W. C. SCHROEDER. 1939. Notes on the fauna above mud bottoms in deep water in the Gulf of Maine. Bio. Bull., 76(3): 305-324.

1953. Fishes of the Gulf of Maine. U.S. Fish Wild. Serv., Fish. Bull., 53: 1-577.

BISHOP, C. A. MS 1994. Revisions and additions to stratification schemes used during research vessel surveys in NAFO Subareas 2 and 3. NAFO SCR Doc., No. 43, Serial No. N2413, 23 p. (revised).

BRIGHT, T. J. 1970. Food of deep-sea bottom fishes. In: Contributions on the biology of the Gulf of Mexico. W.E. Pequegnat and F.A. Chace [ed.]. Texas A\&M Univ. Oceanogr. Stud., 1: 245-252.

BULLIS, H. R., and P. J. STRUHSAKER. 1970. Fish fauna of the western Caribbean upper slope. Quart. J. Fla. Acad. Sci., 33: 43-76.

COHEN, D. M. 1977. Swimming performance of the gadoid fish (Antimora rostrata) at 2400 meters. Deep Sea Res., 24: 275-277.

CROSS, F. A., L. M. HARDY, N. Q. JONES, and R. T. BARBER. 1973. Relation between total body weight and concentrations of manganese iron, copper, iron, zinc and mercury in white muscle of bluefish (Pomatus saltatrix) and a bathydemersal fish (Antimora rostrata). J. Fish. Res. Board Can., 30: 1287-1291.

DOUBLEDAY, W. G. 1981. Manual on groundfish surveys in the Northwest Atlantic. NAFO Sci. Coun. Studies, 2: $55 \mathrm{p}$.

GAULDIE, R. W., G. COOTE, K. P. MULLIGAN, I. F. WEST, and N. R. MERRETT. 1991. Otoliths of deepwater fishers: structure, chemistry and chemically-coded life histories. Comp. Biochem., 100A(No. 1): 1-31.

GOODE, G. B., and T. H. BEAN. 1879. Description of two gadoid fishes, (Phycis chesteri) and Haloporphyrus viola from the deep sea fauna of the Northwestern Atlantic. Proc. U.S. Natl. Mus., 1: 256-260.

1895. Oceanic Ichthyology. A treatise on the deepsea and pelagic fishes of the world, based chiefly upon the collections trade by the steamers Blade, Albatross and Fishhawk in the northwestern Atlantic. Smithonian Contrib. Knowl., 30(xxv): 553.

GORDON, J. D. M, and J. A. R. DUNCAN. 1985. The biology of fish of the family Moridae in the deep-water of the Rockall Trough. J. Mar. Biol. Assoc. UK, 65(2): 475485.

GORDON, J. D. M., N. R. MERRETT, O. A. BERGSTAD, and S. C. SWAN. 1996. A comparison of the deep-water demersal fish assemblages of the Rockall Trough and Porcupine Seabight, eastern North Atlantic: continental slope to rise. J. Fish Biol., 49 (Suppl. A): 217-238.
GRAHAM, M. S., R. L. HAEDRICH, and G. L. FLETCHER. 1985. Heamatology of three deep-sea fishes: A reflection of low metabolic rates. Comp. Biochem. Physiol., 80A: $79-84$.

GREY, M. 1956. The distribution of fishes found below a depth of 2000 meters. Fieldiana Zool., 36: 73-337.

HAEDRICH, R. L., and P. T. POLLONI. 1974. Rarely seen fishes captured in Hudson Submarine Canyon. J. Fish. Res. Board Can., 31: 231-234.

HAEDRICH, R. L., G. T. ROWE, and P. T. POLLINI. 1975. Zonal and faunal composition of epibenthic populations on the continental slope south of New England. J. Mar. Res., 33: 191-212.

HAEDRICH, R. L., and G. KREFFT. 1978. Distribution of bottom fishes in the Denmark Strait and Irminger Sea. Deep Sea Res., 25: 705-720.

HAEDRICH , R.L., G.T. ROWE AND P.T. POLLONI. 1980. The megabenthic fauna in the deep sea south of New England, USA. Mar. Biol., 57: 165-179.

HUBBS, G. L., and K. F. LAGLER. 1970. Fishes of the Great Lakes Region. Univ. Mich. Press, $4^{\text {th }}$ ed. 213 p.

IWAMOTA, T. 1975. The abyssal fish Antimora rostrata (Günther) pressure effects on biochemical systems of abyssal and midwater organisms: The 1973 Kona Expedition of the Alpha Helix. P.W. Hochachka (ed.). Comp. Biochem. and Physiol., 52(1B): 7-11.

JOSEPHSON, R. V., R. B. HOLTZ, J. P. MISCOCK, and C. F. PHLEGER. 1975. Composition and partial protein characterization of swimbladder foam from deep-sea fish Coryphaenoides acrolepis and Antimora rostrata. Comp. Biochem. Physiol., 52B: 91-95.

KULKA, D. W. MS 1998. SPANdex - SPANS geographic information system process manual for creation of biomass indices and distributions using potential mapping. DFO Atl. Fish. Res. Doc., No. 60, 28 p.

KULKA, D. W., and J. R. FIRTH. MS 1987. Observer Program Training Manual - Newfoundland Region. Can. Tech. Rep. Fish. Aquat. Sci., 1355 (revised): 197 p.

MAGNUSSON, J. V. MS 1998. Age, maturity and other biological parameters of two morid species Lepidion eques (Günther, 1887) and Antimora rostrata (Günther, 1878) in Icelandic waters. ICES C.M. Doc., No. O:32: $22 \mathrm{p}$.

2001. Distribution and some biological parameters of two morid species Lepidion eques (Günther, 1887) and Antimora rostrata (Günther 1887) in Icelandic waters. Fish Res., 1206: 1-15.

MARKLE, D. F., and J. A. MUSICK. 1974. Benthic slope fishes found at $900 \mathrm{M}$ depth along a transect in the western N. Atlantic Ocean. Mar. Biol., 26: 225-233.

MARSHALL, N. B., and D. W. BOURNE. 1964. A photographic survey of benthic fishes in the Red Sea and Gulf of Aden, with observations on their population density, diversity and habits. Bull. Mus. Comp. Zoo., 123: 223-244.

MERRETT, N.R. and N. B. MARSHALL. 1980. Observations on the ecology of deep sea bottom living fishes collected off northwest Africa $08^{\circ}-27^{\circ}$ N. Prog. Oceanography, 9: $185-244$. 
MUSICK, J.A., C.A. WENNER and G.R. SEED-BERRY. MS 1975. Archibenthic and abyssobenthic fishes of deepwater dumpsite 106 and the adjacent area. NOAA Dumpsite Evaluation Rep., 75-1: 229-269.

MUUS, B., F. SALOMONSEN, and C. VIBE. 1990. Grønlands fauna (Fisk, Fugle, Pattedyr). Gyldendalske Boghandel, Nordisk Forlag A/S København, 464 p. (in Danish).

PARSONS, L.S. 1976. The blue hake (Antimora rostrata), p.23-25. In: A.T. Pinhorn (ed.). Living marine resources of Newfoundland-Labrador: status and potential. Bull Fish. Res. Board Can., 194: 64 p.

PHLEGER, C. F. 1975. Lipid synthesis by Antimora rostrata, an abyssal codling from the Kona Coast. Comp. Biochem Physiol., 52B: 97-99.

POLLONI, P. T., R. L. HAEDRICH, G. T. ROWE, and C. H. CLIFFORD. 1979. The size depth relationship in deep ocean animals. Int. Revue Ges. Hydrobiol., 64: 39-46.

PRIEDE, I. G., P. M. BAGLEY, A. SMITH, S. CREASY, and N. R. MERRETT. 1994. Scavenging deep demersal fishes of the Porcupine Seabight, north-east Atlantic: Observations by baited camera trap and trawl. J. Mar. Biol. Ass. U.K., 74(3): 481-498.

RÄTZ, H.-J. 1999. Structures and Changes of Demersal Fish Assemblage off Greenland, 1982-96. NAFO Sci. Coun. Studies, 32: 1-15.

SANCHES, J. G. 1989. Nomenclatura Portuguesa de organismos aquáticos (proposta para normalizaçao estatística). Publicaçoes avulsas do I.N.I.P., No. 14, $322 \mathrm{p}$.
SCHROEDER, W. C. 1940. Some deep sea fishes from the North Atlantic. Copeia, 4: 231-238.

1955. Report on the results of exploratory ottertrawling along the continental shelf and slope between Nova Scotia and Virginia during the summers of 1952 and 1953. Deep Sea Res. (Suppl. Pap. Mar. Biol. Oceanogr.), 3: 358-372.

SEDBERRY, G. R., and J. A. MUSICK. 1978. Feeding strategies of some demersal fishes of the continental slope and rise off the mid-Atlantic coast of the U.S.A. Mar. Biol., 44: 357-375.

SMALL, G. J. 1981. A review of the bathyal fish genus Antimora (Moridae: Gadiformes). Proc. Cal. Acad. Sci., 42(13): 341-348.

SNELGROVE, P. V. R., and R. L. HAEDRICH. 1985. Structure of the deep demersal fish fauna off Newfoundland. Mar. Ecol. Prog. Ser., 27: 99-107.

SOMERO, G. N., and J. F. SIEBENALLER. 1979. Inefficient lactate dehydrogenases of deepsea fishes. Nature, 282: 100-102.

SULAK, K. J. 1984. A comparative ecological analysis of temperate and tropical demersal deep-sea fish faunas in the western North Atlantic. Ph. D. thesis, Univ. Miami, USA, p. 1-211.

VASQUEZ, J. 1991. Contribucion al estudio de la biologica de Antimora rostrata, Günther, 1878 (Pices, Moridae). Biol. Inst. Esp. Oceanogr., 7: 59-66.

WENNER, C. A., and J. A. MUSICK. 1977. Biology of the morid fish, (Antimora rostrata) in the Western north Atlantic. J. Fish. Res. Board Can., 34: 2362-2368. 